\title{
Human Security in Turkey
}

Challenges for the 21 st century

Edited by

Alpaslan Özerdem and

Füsun Özerdem 


\section{Human Security in Turkey}

This edited volume explores human security challenges in the context of Turkey.

Turkey occupies a critical geopolitical position between Europe, the Middle East and the Caucasus. It is an important peace-broker in regional conflicts and a leading country in peacekeeping operations, and has been a generous donor for disaster response around the world. However, Turkey is also facing a number of fundamental sociocultural and development challenges and its internal stability is affected by a protracted armed conflict based on Kurdish separatism. In other words, Turkey is at a crossroads in its transformation from a state-centred security perspective to one based on human security.

To explore selected human security challenges within a wider context of peace and development, this volume focuses on a number of key issues in relation to democratization and social cohesion, before going on to investigate the role of Turkey as an agent of peace in the international context. Written by academics from the fields of peace studies, international relations, politics and development studies, the discussions examine and highlight the issues that Turkey must overcome if it is to successfully strengthen its human security trajectories in the near future.

This book will be of much interest to students of human security, Turkish politics, conflict management, peace studies and IR in general.

Alpaslan Özerdem is Professor of Peacebuilding and Director of the Centre for Peace and Reconciliation Studies at Coventry University, UK. He is co-editor of Participatory Research Methodologies in Development and Post Disaster/Conflict Reconstruction (2010) and co-author of Managing Emergencies and Crises (2011), among other books. He is also Chief Editor of the Journal of Conflict Transformation and Security.

Füsun Özerdem is Assistant Professor in Political Science and International Relations at Muğla Sıtkı Koçman University, Turkey. Her main areas of expertise are EU regional policy, Turkey's accession to the EU, cross-border cooperation programmes, EU social policy and human security. 


\section{Series: Security and Conflict Management}

Series Editors:

Fen Osler Hampson

Carleton University, Canada

Chester Crocker

Georgetown University, Washington DC

Pamela Aall

United States Institute of Peace, Washington DC

This series will publish the best work in the field of security studies and conflict management. In particular, it will promote leading-edge work that straddles the divides between conflict management and security studies, between academics and practitioners, and between disciplines.

\section{Negotiation and Conflict Management}

I. William Zartman

\section{Conflict Management and African Politics}

Negotiation, mediation, and politics

Terrence Lyons and Gilbert M. Khadiagala (eds)

\section{International Conflict Mediation}

New approaches and findings

Jacob Bercovitch and Scott Sigmund Gartner (eds)

\section{International Mediation in Civil Wars}

Bargaining with bullets

Timothy D. Sisk

\section{Conflict Transformation and Peacebuilding}

Moving from violence to sustainable peace

Bruce Dayton and Louis Kriesberg (eds)

Theory and Practice of International Mediation

Selected essays

Jacob Bercovitch

\section{UN Sanctions and Conflict}

Responding to peace and security threats

Andrea Charron 
Territorial Disputes and Conflict Management

The art of avoiding war

Rongxing Guo

Aid, Insurgencies and Conflict Transformation

When greed is good

Rob Kevlihan

Human Security in Turkey

Challenges for the 21st century

Alpaslan Özerdem and Füsun Özerdem (eds) 
This page intentionally left blank 


\section{Human Security in Turkey Challenges for the 21st century}

\section{Edited by Alpaslan Özerdem and Füsun Özerdem}

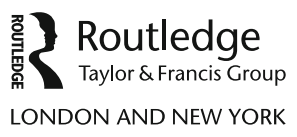


First published 2013

by Routledge

2 Park Square, Milton Park, Abingdon, Oxon, OX14 4RN

Simultaneously published in the USA and Canada

by Routledge

711 Third Avenue, New York, NY 10017

Routledge is an imprint of the Taylor $\mathcal{E}$ Francis Group, an informa business

(C) 2013 selection and editorial material, Alpaslan Özerdem and Füsun Özerdem; individual chapters, the contributors

The right of the editors to be identified as the authors of the editorial material, and of the authors for their individual chapters, has been asserted in accordance with sections 77 and 78 of the Copyright, Designs and Patents Act 1988.

All rights reserved. No part of this book may be reprinted or reproduced or utilized in any form or by any electronic, mechanical, or other means, now known or hereafter invented, including photocopying and recording, or in any information storage or retrieval system, without permission in writing from the publishers.

Trademark notice: Product or corporate names may be trademarks or registered trademarks, and are used only for identification and explanation without intent to infringe.

British Library Cataloguing in Publication Data

A catalogue record for this book is available from the British Library

Library of Congress Cataloging in Publication Data

Human security in Turkey : challenges for the 21st century / edited by Alpaslan Özerdem and Füsun Özerdem.

pages $\mathrm{cm}$. - (Security and conflict management ; 10)

Includes bibliographical references and index.

1. Human security-Turkey. 2. Human rights-Turkey.

3. Civil society-Turkey. I. Özerdem, Alpaslan.

II. Ozerdem, Füsun.

JC599.T87H876 2013

$355^{\prime} .0330561-\mathrm{dc} 23$

2013002617

ISBN: 978-0-415-81073-9 (hbk)

ISBN: 978-0-203-58430-9 (ebk)

Typeset in Baskerville

by Wearset Ltd, Boldon, Tyne and Wear 
To our parents, Hasan Hüseyin and Leyla Özerdem 
This page intentionally left blank 


\section{Contents}

Notes on contributors $\quad$ xi

Foreword: human security - a practitioner's perspective $\quad \mathrm{xv}$

FILIPPO GRANDI

Acknowledgements $\quad \mathrm{xx}$

List of abbreviations $\quad \mathrm{xxi}$

Introduction $\quad 1$

1 Human(secur)ity and its subjects $\quad 11$

OLIVER P. RICHMOND

\section{PART I}

Democratization and social cohesion 35

2 Minority protection: a thorny issue in Turkish-EU relations 37

ÖZDEN ZEYNEP OKTAV

3 What went wrong with the 'Romani Opening' in Turkey? 56

FUNDA GENÇO ĞLU ONBAŞI

4 Teaching national security or peace? The case of the Turkish national curriculum

BEZEN BALAMIR COŞKUN AND HALIT HAKAN EDI $\breve{G}$

5 Democratization, conflict transformation and women's organizations

SANEM ÖZER

6 Social exclusion and local authorities: a case study of Ístanbul 
x Contents

7 Uncertain past, uncertain future, uncertain present: social cohesion and conflicts in Iğdır Province

GIACOMO GOLINELL I

\section{PART II}

Turkey as an agent of peace and security

8 Religion in Turkey's domestic and international agendas: human security perspectives

FÜSUN ÖZERDEM AND ALAN HUNTER

9 Turkey: bridging Europe and Islam DEVRIM ÜMİT

10 Securitization and externalization of the migration practices in the EU: readmission agreements and the Turkish case

B URCU TO ĞRAL

11 Termination of the vendetta of the Black Sea? Stable peace, energy security and Russian-Turkish relations RESAT BAYER

12 Turkey's human security agenda in the Gaza Strip IB RAHIM NATIL

Conclusion

Index 


\section{Contributors}

Reşat Bayer is Assistant Professor of International Relations at Koç University. His primary research interests are international cooperation and conflict. He is particularly interested in peace within countries and between countries, how peaceful relations emerge, and the role of conflict management and resolution in peaceful relations, including negotiation and mediation. His current projects are on peaceful change and revenge, power transitions in the Middle East, terrorism and electoral politics, independence and violence, diplomatic relations and democracy. His recent work has appeared or will be appearing in the Journal of Peace Research, Conflict Management and Peace Science, Globalizations, International Studies Quarterly and the British Journal of Political Science.

Bezen Balamir Coşkun is Assistant Professor at Zirve University, Turkey. She holds an M.Sc. from Aalborg University, Denmark, and a Ph.D. from Loughborough University, UK. Her doctoral research, Analysing Desecuritisation: The Case of the Israeli-Palestinian Peace Education and Water Management, was published by Cambridge Scholars Publishing. Her research fields are the security and politics of the Middle East. She has published several articles, book chapters and research papers on Middle East politics and security.

Halit Hakan Ediğ is Research Assistant in the Department of International Relations of Zirve University. He graduated from Bilkent University's International Relations undergraduate programme in 2007. He received his MA degree on Security Strategies and Management. His Master's dissertation was Relation of Proficiency Associations and Civil Society. He is now a Ph.D. student on the Police Academy, Security Strategies and Management programme.

Funda Gençoğlu Onbaşı received her BA and MA degrees from the Department of Political Science and Public Administration at Bilkent University. After five years' work experience in the private sector, she started her doctoral study at Middle Eastern Technical University and received her Ph.D. in Political Science in 2008. She currently teaches 
in the Department of Political Science and International Relations at Başkent University. She has published articles, books and book chapters on civil society in Turkey, the women's rights movement in Turkey, Turkish political parties, the early Republican period in Turkey, September 11 and its effects, democracy theory, constitution-making and conscientious objection.

Giacomo Golinelli is a Ph.D. candidate in Anthropology at the University of Bologna, Italy. He works on public space organization, nationalist and religious behaviours, social memory and travel literature. He has done fieldwork in Turkey, in İstanbul and the İzmir area. Currently he is conducting research in eastern Turkey, a border area in Southern Caucasus close to Armenia and Nakhchivan.

Filippo Grandi was appointed as Deputy Commissioner-General of the United Nations Relief and Works Agency for Palestine Refugees in the Near East (UNRWA) in 2005 and has been the Commissioner-General of the organization since 2010. Prior to his appointments at UNRWA, he served as Deputy Special Representative of the Secretary-General responsible for political affairs at the United Nations Assistance Mission in Afghanistan (UNAMA) and Chief of Mission of the United Nations High Commissioner for Refugees (UNHCR) in Afghanistan from 2001 onwards. With UNHCR, he also served in a variety of other countries, including Sudan, Syria, Turkey and Iraq after the first Gulf War. He also headed a number of emergency operations, including in Kenya, Benin, Ghana, Liberia, the Great Lakes Region of Central Africa and Yemen. He has a Bachelor's degree in Philosophy from the State Universities of Venice and Milan and from the Gregorian University in Rome.

Alan Hunter is Professor of Asian Studies at Coventry University, UK, and Associate Director of the Centre for Peace and Reconciliation Studies. He holds a Ph.D. in Religious Studies and also a D.Litt. for his work on peace, religion and human security. His publications include New Perspectives on Human Security (2010, with Malcolm McIntosh) and 'Chinese soft power on the global stage' (Chinese Journal of International Politics, 2, 2009). In 2012, he was Visiting Professor at Doshisha University, Kyoto, Japan.

İhsan İkizer is a Ph.D. candidate at the Centre for Sociological Research at KU Leuven University, Belgium. He did his Master's degree at the European Union Institute at Marmara University, Turkey. His research interests include the voluntary sector, local authorities, urban governance, and social exclusion and inclusion.

Ibrahim Natil has a Ph.D. in Politics and History from Coventry University, UK and an MA in Diplomatic Studies from the University of Westminster, UK. He is a Founder and Director General of Society Voice Foundation, 
which specializes in human rights education, peacebuilding and good governance, and operates in the occupied Palestinian territories. He has also worked as a consultant and employee for a number of international and national organizations since 1997. He contributes to and supervises a number of media outlets in Arabic, and has presented papers at international conferences.

Özden Zeynep Oktav is Associate Professor and Lecturer in the Department of Political Science and International Relations at Yildiz Technical University. She is the author of Limits of Relations with the West: Turkey, Syria and Iran (2008), Basra Körfezi'nin Değisen Dinamikleri, Iran-ABDSuudi Arabistan İliskileri (2011) and various book chapters and articles, and the editor of Turkey in the 21st Century: Quest for a New Foreign Policy (2011).

Sanem Özer is Assistant Professor in the Department of International Relations at Akdeniz University. She received her Bachelor's degree from Bilkent University in 1999, a Master's degree in European Studies from the University of Exeter in 2000, and her Ph.D. in EU Politics and International Relations from Marmara University in 2006. Her fields of research interest are European foreign policy, South Caucasus, conflict resolution and civil society.

Alpaslan Özerdem is Professor of Peacebuilding and Director of the Centre for Peace and Reconciliation Studies at Coventry University, UK. With over 15 years of field research experience in Afghanistan, BosniaHerzegovina, El Salvador, Kosovo, Lebanon, Liberia, the Philippines, Sierra Leone, Sri Lanka and Turkey, he specializes in the politics of humanitarian interventions, disaster response, security sector reform, reintegration of former combatants and post-conflict state building. He has also taken an active role in the initiation and management of several advisory and applied research projects for a wide range of national and international organizations. He has published extensively in peerreviewed international journals and is co-author of Disaster Management and Civil Society: Earthquake Relief in Japan, Turkey and India (2006), author of Post-war Recovery: Disarmament, Demobilisation and Reintegration (2008), co-editor of Participatory Research Methodologies in Development and Post Disaster/Conflict Reconstruction (2010), co-author of Managing Emergencies and Crises (2011); co-editor of Child Soldiers: From Recruitment to Reintegration (2011) and co-editor of Challenging Post-conflict Environments: Sustainable Agriculture (2012).

Füsun Özerdem is Assistant Professor in Political Science and International Relations at Muğla Sıtkı Koçman University. She has a Ph.D. in European Union Studies from İstanbul University and a Master's degree in International Relations from Trakya University, Edirne. She is the Founder Coordinator of the Governorship of Edirne European 
Union Coordination Centre and Edirne EU Info Centre. Since April 2009, she has also served as Turkey Coordinator on the West Africa North Asia (WANA) Forum. She prepares EU-funded projects, and has monitored and evaluated projects within the Bulgaria-Turkey Crossborder Cooperation Programme on behalf of the EU. Her main areas of expertise are EU regional policy, Turkey's accession to the EU, crossborder cooperation programmes, EU social policy and human security.

Oliver P. Richmond is Research Professor at the Humanitarian and Conflict Response Institute and Department of Politics at the University of Manchester. He is also International Professor in the School of International Studies at Kyung Hee University, Korea. His publications include A Post Liberal Peace (2011), Liberal Peace Transitions (with Jason Franks, 2009), Peace in IR (2008) and The Transformation of Peace $(2005 / 7)$. He is the editor of the Palgrave book series Rethinking Conflict Studies.

Burcu Togral completed her undergraduate studies in International Relations and Sociology at the Middle East Technical University, Ankara. She received an MA in European Studies from the University of Hamburg and is currently a Ph.D. candidate there. During her Ph.D. study, she stayed as a visiting scholar at the University of Kent, Brussels, and the Fundación José Ortega y Gasset, Madrid. She has also been involved in the work of the Refugee Council Hamburg for several years. Her most recent publication is 'Convergence of securitization of migration and "new racism" in Europe: rise of culturalism and disappearance of politics' (2011).

Devrim Ümit is Assistant Professor and the Founding Chair in the Department of International Relations at the Faculty of Economics and Administrative Sciences in Karabuk University, Turkey. Receiving her Ph.D. in History from Columbia University, USA, in 2008, She is a specialist in transnational history, the modern Middle East, the late Ottoman Empire and American missionaries, and has numerous international presentations and publications on those topics. She is currently preparing her dissertation for publication, entitled The American Missionary Network in Ottoman Turkey, 1876-1914: Political and Cultural Reflections of the Encounter. She also works as an adviser on North Africa and the Middle East at the International Middle East Peace Research Center, a non-profit think tank based in Ankara, Turkey. 


\title{
Foreword
}

\section{Human security - a practitioner's perspective}

\author{
Filippo Grandi
}

Addressing human security is vital in finding peace and it is appropriate that the Human Security Conference be held in Turkey, a pivotal country with increasing influence in a region where security is complex and fragile; a region, however, where political calculations far too regularly trump the rights, hopes and aspirations of the people. You will appreciate that this is especially important from the point of view of my organization, UNRWA, the United Nations agency providing protection and assistance to Palestine refugees.

My first overseas assignment was as a young volunteer with an NGO working on the Thai-Cambodian border back in 1984. During my first week, I was in a field hospital built for refugees fleeing the war in Cambodia and a young mother lay before me - helpless - as her baby son died of malaria in her arms.

I had prepared myself for the overall situation. I had read books about the Indochinese wars; studied reports about refugee camps; spoken with people who had served in similar situations.

And yet nothing prepared me for that experience and my first full and tangible realization of what conflict and forced displacement concretely mean for people's lives. How they turn them inside out; destroy their health, their livelihoods, their relationships, their dignity and their hopes. As I watched the mother's emotions move between rage at her predicament and those who had caused it, and overwhelming despair at her son's death, I also somehow understood that real peace would not be achieved until that tragic pain - her pain - had been addressed and until the lives of those sharing her plight had been rebuilt.

It was at that moment that one thing became clear to me: I wanted to try and deal with crises as my life's work, but I wanted to do so from the human side of the spectrum. If I had been using today's language, I would have said that I wanted to deal with human security.

Humanitarians, of whom I am one, are experts in one critical and fundamental aspect of human security. Humanitarian work is focused on people and meeting their most basic needs in situations of crisis. We deal only, however, with 'short-term' human security in situations where it is 
critically and immediately threatened, hoping and expecting others to address the political and longer-term developmental challenges early and decisively to bring human insecurity to an end.

My main experience has been working for refugees and addressing crises in a variety of places. I was privileged to work for some years with the former UN High Commissioner for Refugees, Sadako Ogata, who - as you know has done valuable work on human security. Like her, I believe that refugees are a very useful lens through which to analyse human security issues. Why would someone leave their home, job and education, and make a decision to either abandon their family or expose them to hazards and dangers; why would anybody embrace a life of complete insecurity unless they felt even more gravely insecure in their own homes and countries?

Refugees tell us first and foremost that if crises are to be addressed effectively, the human element of war must be appropriately tackled. I thought, therefore, that I would use the refugee angle to share with you five thoughts.

First, human security issues are complex, and crises that cause them must be dealt with through a variety of actors and interventions whose timing and sequencing are key. Regrettably, in my experience, the synergy and synchrony of these crucial elements do not always work well.

I lived in Afghanistan from 2001 to 2005 and helped coordinate the return of millions of refugees after decades in exile. The end of the Taliban regime in 2001 was a good opportunity to build peace in that country. One could very well argue that the Bonn Agreement in 2001 was a reasonably successful, even if imperfect, political milestone towards peace, rightly complemented by the international community's quick focus on humanitarian needs. Funds flowed rapidly and substantively into urgent interventions, such as a crucial back-to-school initiative, food security programmes and large immunization campaigns, helping shape an environment of basic human security, and thus paving the way for another key operation, the voluntary return of refugees.

But while these proved successful interventions, they were not followed by a similarly rapid investment in post-conflict rehabilitation, reconstruction and development to complete or build upon the Bonn Agreement's initial achievements. Resources invested in things that make human security durable and predictable - roads and electricity, for example, but also an effective police and a trustworthy judiciary - were slow, late and inadequate. There were other factors, of course, but these failures undoubtedly contributed to the deterioration in the conditions in the country, and to the weakening of the sense of human security. I remember speaking to returnees who felt insecure again, and started doubting their decision to repatriate.

Second, human security lends itself to dangerous political manipulation from a completely different angle, especially in situations of crisis. In particular, crises involving refugee flows highlight a somehow paradoxical 
aspect of human security: the ability of this concept to be exploited for political means.

The fear of strangers has coexisted with humanity since time immemorial. In the complex contemporary situations of population movements that include refugees and illegal migrants, however, politicians stressing the threats to employment and safety - particularly in Europe, but elsewhere as well - have become a very common feature. The result of this skilful manipulation of feelings of insecurity has actually been further insecurity for all: for refugees and migrants, subjected to hostility, marginalization, deportation and worse; and for receiving communities, whose fears are aroused in order to gain political support.

The (correct) perception that 'strangers' - refugees, migrants - can make contributions to societies and communities hosting them, adding to their prosperity and their culture, has unfortunately little or no electoral traction. This phenomenon highlights the ambiguities that can surround the notion of human security, and it is important to counter it in the strongest and most effective manner.

Third, addressing the human element of conflict is crucial also in finding solutions. Let me use the refugee lens again. The act of fleeing war and conflict in itself causes insecurity both on a personal level and in communities, countries and regions. In fact, refugee movements are both a consequence and a factor of human insecurity. Thus it is only when they are solved that conditions for a real and lasting peace can be achieved and those affected can move on with a future that is theirs to build. Anything less than this leaves refugees in a state of limbo, uncertainty and continued insecurity that reverberate beyond refugees themselves.

In places where comprehensive peace agreements have been fully implemented, including durable solutions for refugees, peace has been more robust, and has offered better opportunities for development and prosperity. This lesson has been demonstrated in many situations, such as with the Indochinese boat people and other refugees in South-East Asia, in several countries of Central America towards the end of the Cold War and in Mozambique after the civil war, to name just a few examples.

Fourth, the definition of security and insecurity is an important feature which merits attention. Here I would be remiss of course if I did not mention the refugee situation which I have been confronted with in the past few years, that of the Palestinians. Many human security lessons can be drawn from their plight. They are part of a conflict which is correctly presented as a threat to security - but this definition is almost invariably partial: a conflict threatening the security of Israel and of other governments in the region, threatening regional security, even threatening global security. These portrayals of the conflict do not encourage political actors to look at its deeper consequences, those affecting all the people involved - Israelis and Palestinians alike - but especially those, such as the Palestine refugees, who are the most exposed and affected. Security is delinked 
from real lives, and this is nowhere more evident than in the dynamics of Israeli occupation of the Palestinian territory.

Human security in a divided region can only be achieved if it is shared, but - obvious as it is - this basic truth is conveniently ignored. Instead of trying to tackle comprehensively the causes of insecurity, the issue is thus addressed selectively - with the result that measures aimed at protecting one people often affect the security of the other. The wall built by Israel and splitting Palestinian land is a true symbol, in my opinion, of how human security should not be addressed, not only because it runs against the tenets of international law, but also because it is a factor of profound, dramatic insecurity for thousands of Palestinians cut off from their land, services and families.

Through our work with refugees, we at UNRWA are well placed to assess how this conflict and the absence of human security impact their everyday lives. A Palestinian farmer or businessman in the West Bank is often forced to spend more time navigating checkpoints than tending to his fields or conducting his business. A mother from Gaza has to face a crisis that is often ill-defined as humanitarian, but which is in fact much greater. It encompasses all aspects of life - her savings, her family relations, her education and health, her drinking water, her sanity and every other aspect of life as she is constrained in one of the world's most densely populated areas with 1.5 million others. The profound insecurity generated by the occupation of Palestinian land and people is not addressed, thus making peace much more difficult.

And finally, and by the same token, Palestine refugees, now approaching five million in the region, are often only partially or even superficially presented to the international community as a 'final status issue' - an abstract political and politicized matter - rather than as people in exile; a painful and decades-long exile away from their homes, their land, their history, with no solution in sight.

What is frequently forgotten is that they represent the human consequence of a protracted conflict which must also be addressed if peace is to be achieved. This brings me to my fifth and final point. It is remarkable that, over the long years of the so-called 'peace process', little or no consultation has occurred with refugee communities about their future. This is a significant exclusion, and one that could eventually prove fatal to peace efforts, especially at a time when the 'Arab Spring' has made it impossible for political leaders, finally, to ignore the voice of the people. Because while the conflict must of course be solved in the political domain, a lasting solution will be impossible if it does not rest on understanding, acceptance, participation and finally ownership by all the people affected by the conflict itself - including in particular one of its most important constituencies, the refugees.

Today, nearly 30 years on, I still think of that young mother on the Thai-Cambodian border, and a measure of pain and loss I can only try to 
imagine. If she has survived her ordeal, she must be a woman in her middle age, perhaps with children and grandchildren, living in a Cambodian village. I often wonder what happened to her after the death of her son on that fateful day; how - and if - she was able to move past her extraordinary suffering; what support she received outside the walls of that field hospital. Was she - and the countless like her - provided with the basics? Did the peace process allow her to rebuild her life following the war and terror that drove her from everything she knew, and the pain that she encountered while in exile? Was she able, even in small ways, to influence and participate in the process?

Peace has now come to Cambodia, but did it truly reach her? This is the question I asked in concluding my keynote speech at the first Istanbul Human Security Conference on 27 October 2011. It is very much with the purpose of exploring a wide range of such human security challenges that the Centre for Peace and Reconciliation Studies (CPRS) at Coventry University, jointly with Turkish university partners, organizes the abovementioned conference series.

The conference which I inaugurated, with an overall theme of 'Human Security: New Challenges and New Perspectives', hosted more than 60 academic papers from more than 100 participants, representing 40 different academic organizations from around the world. It was an excellent initiative to investigate how various human security challenges have been addressed in different contexts, and what lessons could be learned from such experiences. For me, it was particularly striking to see that those human security challenges which first confronted me in Cambodia years ago, and which I encountered throughout my professional life in different situations, continue to define contemporary crisis contexts.

Therefore, this edited volume, incorporating papers from the 2011 İstanbul Human Security Conference, has my full support because it is imperative that we learn from each other's experiences in order to respond to human security challenges more effectively.

I was particularly pleased that this edited volume focuses on Turkey in respect of the exploration of human security challenges. This will bridge a major gap in the literature. Turkey plays an important role in responding to a wide range of human security challenges in its immediate region and also internationally. However, like for many other countries, there are significant human security concerns that are yet to be addressed in Turkey itself.

Therefore, this volume will be an important guide to those who try to understand how an emerging power like Turkey deals with human security challenges both within and internationally. Such a focus on a particular country is also necessary in order to understand and appreciate interrelationships between different human security challenges and how they converge with each other in terms of national and international dynamics, the existence of several decision-making levels and the role of different actors and agendas. 


\section{Acknowledgements}

This book is a product of the CPRS Turkey Peace and Security Studies initiative at the Centre for Peace and Reconciliation Studies at Coventry University. Funded jointly by the Ferguson Trust and Coventry University, the initiative explores a wide range of conflict and peace-related matters in the context of Turkey and on the role of Turkey at regional and international levels. One of the primary activities of the CPRS Turkey initiative is to hold an annual international conference series on human security in İstanbul, and the contributions in this volume were presented at the October 2011 conference. Therefore, we would like to thank our colleagues and students both in the UK and in Turkey for working diligently with us in the organization of this human security conference series each year.

We would also like to thank Fen Osler Hampson, Chester Crocker and Pamela Aall, series editors of Routledge Security and Conflict Management, for their encouraging inputs in the development of this volume.

Finally, our sincere thanks go to Merlin Cox, our copy editor, for his thorough work and the team at Routledge, Andrew Humphrys and Annabelle Harris, for their excellent support throughout this project. 


\section{Abbreviations}

$\begin{array}{ll}\text { AKP } & \text { Justice and Development Party } \\ \text { BDP } & \text { Peace and Democracy Party } \\ \text { BRICS } & \text { Brazil, Russia, India, China, South Africa } \\ \text { CHP } & \text { Republican People's Party } \\ \text { COREPER } & \text { Committee of Permanent Representatives } \\ \text { CSBR } & \text { Coalition for Sexual and Bodily Rights in Muslim Societies } \\ \text { CATOM } & \text { Multi-Purpose Community Centres } \\ \text { DTP } & \text { Democratic Society Party } \\ \text { ECHR } & \text { European Court of Human Rights } \\ \text { EDROM } & \text { Edirne Roma Association } \\ \text { EHESS } & \text { School for Advanced Studies in the Social Sciences } \\ \text { ERF } & \text { European Refugee Fund } \\ \text { EU } & \text { European Union } \\ \text { FES } & \text { Friedrich-Ebert-Stiftung } \\ \text { G7+ } & \text { Group of Seven and Russia } \\ \text { G20 } & \text { Group of Twenty } \\ \text { GDP } & \text { Gross Domestic Product } \\ \text { HS } & \text { Human Security } \\ \text { IBSA } & \text { India, Brazil, South Africa } \\ \text { ICCPR } & \text { International Convention on Civil and Political Rights } \\ \text { ICG } & \text { International Crisis Group } \\ \text { IDRC } & \text { International Development Research Centre } \\ \text { IHH } & \text { Foundation for Human Rights and Freedoms and } \\ & \text { Humanitarian Relief } \\ \text { IMM } & \text { İstanbul Metropolitan Municipality } \\ \text { INGO } & \text { International Nongovernmental Organization } \\ \text { IO } & \text { International Organization } \\ \text { IR } & \text { International Relations } \\ \text { ISMEK } & \text { İstanbul Metropolitan Municipality Art and Vocational } \\ & \text { Training Courses } \\ \text { KADER } & \text { Association for the Support of Women } \\ \text { KAGIDER } & \text { Women Entrepreneurs' Union of Turkey } \\ \text { KAMER } & \text { Women's Centre Foundation } \\ & \end{array}$




$\begin{array}{ll}\text { LGBT } & \text { Lesbian, Gay, Bisexual, Transgender } \\ \text { MHP } & \text { Nationalist Movement Party } \\ \text { NATO } & \text { North Atlantic Treaty Organization } \\ \text { NGO } & \text { Nongovernmental Organization } \\ \text { OECD } & \text { Organization for Economic Co-operation and Development } \\ \text { PA } & \text { Palestinian Authority } \\ \text { PKK } & \text { Kurdistan Workers'Party } \\ \text { R2P } & \text { Responsibility to Protect } \\ \text { SIDA } & \text { Swedish International Development Cooperation Agency } \\ \text { TAN } & \text { Transnational Advocacy Network } \\ \text { TGNA } & \text { Turkish Grand National Assembly } \\ \text { TIKA } & \text { Turkish International Cooperation Agency } \\ \text { TOKI } & \text { Public Housing Development Administration } \\ \text { UN } & \text { United Nations } \\ \text { UNDEF } & \text { United Nations Democracy Fund } \\ \text { UNDP } & \text { United Nations Development Programme } \\ \text { UNESCO } & \text { United Nations Educational, Scientific and Cultural } \\ & \text { Organization } \\ \text { UNGA } & \text { United Nations General Assembly } \\ \text { UNHCR } & \text { United Nations High Commissioner for Refugees } \\ \text { UNICEF } & \text { United Nations International Children's Emergency Fund } \\ \text { UNPBSO } & \text { United Nations Peacebuilding Support Office } \\ \text { UNRISD } & \text { United Nations Research Institute for Social Development } \\ \text { UNRWA } & \text { United Nations Relief and Works Agency } \\ \text { USA } & \text { United States of America } \\ \text { USAK } & \text { International Strategic Research Organization } \\ \text { USSR } & \text { Union of Soviet Socialist Republics } \\ \text { VAKAD } & \text { Van Women's Association } \\ \text { WDR } & \text { World Development Report } \\ \text { WHO } & \text { World Health Organization } \\ \text { WWHR } & \text { Women for Women's Human Rights } \\ & \end{array}$




\section{Introduction}

'Peace at home, peace in the world': this is probably one of the best-known sayings of Mustafa Kemal Atatürk, the founder of modern Turkey, which was first uttered in a public speech on 20 April 1931. This statement would be heard at almost all official celebrations in the country, it is taught to children at school, it was placed by the coup d'état leaders as the guide to foreign policy in the 1961 and 1982 constitutions, and it has even been written on mountains by the Turkish army, but has Turkey really achieved this objective over the last 80 years?

Turkey occupies a critical geopolitical position between Europe, the Middle East and the Caucasus. It has a burgeoning economy and a strong, vibrant civil society, and is a member of a wide range of organizations, from NATO and the OECD to the Islamic Conference and G20, with candidacy to the European Union. Turkey is a pivotal player not only in regional but in global affairs. It is an important peace-broker in regional conflicts and a leading country in peacekeeping operations, and has been a generous donor for disaster response around the world. However, Turkey is also a country trying to merge its Islamic heritage into broader structures and models of Western liberal democratic governance. To deal with the legacy of its Ottoman heritage, nation-state-building policies of the Republic and civil-military relationships, Turkey needs to address a number of fundamental sociocultural and development challenges. Furthermore, its internal stability is affected by a protracted armed conflict based on Kurdish separatism.

In other words, Turkey is at a crossroads in its transformation from a state-centred security perspective to one based on human security, which is a people-centred approach to global security that recognizes that lasting peace and social justice cannot be achieved unless people are protected from threats to their rights and basic needs. Among the main human security threats are violence and abuse of human rights, corruption and bad governance, disasters and climate change, and poverty and poor access to basic services. A 1994 United Nations Development Programme report states that, for most people, insecurity arises from worries about daily life - employment, household income, health, the environment and 
crime. The global framework that arose from the report focused on 'survival, dignity and livelihood' to shield people from 'critical and pervasive threats' and 'empower them to take charge of their lives', creating human security through 'freedom from fear and freedom from want' (UNDP 1994: 22-3). Kofi Annan, former Secretary-General of the UN, states that:

Human security in its broadest sense embraces far more than the absence of violent conflict. It encompasses human rights, good governance, access to education and health care and ensuring that each individual has opportunities and choices to fulfil his or her own potential. Every step in this direction is also a step towards reducing poverty, achieving economic growth and preventing conflict. Freedom from want, freedom from fear and the freedom of future generations to inherit a healthy natural environment - these are the interrelated building blocks of human - and therefore national - security.

(Annan 2000)

It is also highly important to recognize that threats to human security are interlinked and demand interdisciplinary responses at international, national and local levels. It is argued that one of the key issues to consider is the interdependence between the developed and underdeveloped regions of the world. The stability of the international system can only be as strong as its weakest link, and therefore risk and vulnerabilities should be perceived from a mutual perspective. The protection of human security, with its five primary sub-areas of environmental, personal and physical, economic, social, and political and cultural realms, would require a combined effort in the areas of human rights, humanitarianism, development and conflict resolution (Nef 1999; Uvin 2004; Axworthy 2001; Bajpai 2000; Glasius 2008; Hampson 2002; Reed and Tehranian 1999).

Turkey today is going through a critical process of ensuring "peace at home' while also facing challenges in acting as an agent of 'peace in the world'. To a great extent, the issue of 'peace at home' has always been assumed as a given without paying much attention to what it really means, whether it even exists and, if not, what could be done to achieve it. Considering that the history of the Turkish Republic is dotted with massacres, pogroms, political violence and an intrastate armed conflict of nearly 30 years with a death toll of over 40,000 people, the assumption of 'peace at home' has yet to be fully substantiated (International Crisis Group 2011; Pope and Pope 2011; Rugman 2001). Apart from the need of finding a peaceful settlement to this protracted armed conflict, the country still faces significant challenges in the realms of 'freedom from fear', 'freedom from want' and 'freedom of living in dignity' too.

Although Turkey has the seventeenth-largest economy in the world, it ranks ninety-second out of 187 countries in the 2011 United Nations Human Development Index, which is towards the bottom end of the 'High 
Human Development' category. In most developed countries, life expectancy at birth is either very close to or over 80 years, while in Turkey it is currently 74 years. Meanwhile, the 'mean years of schooling' in developed countries is at least nine years; it is only 6.5 in Turkey (UNDP 2011). The top 20 per cent income bracket in Turkey accounts for 36.7 per cent of total consumption, while the bottom 20 per cent accounts for only 9.1 per cent. The bottom 20 per cent accounts for only 5.2 per cent of total education spending, compared to 62.3 per cent for the top 20 per cent bracket; similarly, 39.7 per cent of total health spending is absorbed by the top 20 per cent bracket, while the bottom 20 per cent accounts for only 10 per cent (Bekdil 2012). In other words, the country still suffers from a huge wealth gap between the rich and the poor (Öztürk 2007; McClure 2011; Saatçi and Akpınar 2007).

Being part of a minority group, whether based on ethnicity, religion or sexual preference, still carries some social stigma too and such groups are likely to face various difficulties in freely expressing their identity. Consequently, the protection of minority rights continues to be a critical challenge for democratization (Karimova and Deverell 2001; World Directory of Minorities and Indigenous Peoples 2011; Kaya 2009). The country also faces serious gender equality challenges (Rankin and Aytaç 2006). According to the World Bank and Turkey's State Planning Organization, women's share in the overall workforce has in fact decreased from 34 per cent in 1998 to 24 per cent in 2009 . For many in the country, a woman's primary place in society is still the home, and domestic violence rates are believed to be extremely high, yet largely unrecorded (Arat 2009; Sevinç 2011; Müftüler-Baç 2012; USAK 2012; World Economic Forum 2010). It is an unfortunate fact that women are sometimes killed by their own relatives for dishonouring the family. There are still serious governance challenges to do with freedom of expression, transparency and accountability. ${ }^{1}$ These are only some of the critical challenges to be addressed in Turkey in order to ensure the objective of 'peace at home' from a human security perspective.

As far as its role in regional and global peace is concerned, Turkey has not had an interstate armed conflict with any of its eight neighbouring countries since the foundation of its Republic in 1923. However, the relationships with some of its neighbours have been highly problematic, as with Greece, and completely frozen with others, such as Armenia. The military intervention of 1974 in Cyprus for the protection of the Turkish minority on the island has since brought a number of additional challenges to the country's international relations. Moreover, there have been a number of heavy military operations by the Turkish army in northern Iraq in order to root out the Kurdistan Workers' Party (PKK) from the Qandil Mountains, and the current state of affairs with Syria seems to be very close to a declaration of war between the two states. Rising from the ashes of an empire and occupying a territory amid some of the most 


\section{Introduction}

conflict-prone regions of the world has certainly exacerbated the challenge of forming good neighbourly relationships. Furthermore, today Turkey also seems to be making a bid to become the hegemon of its region, which is often referred as the policy of neo-Ottomanism.

In fact, the twenty-first century has so far been a period of rapid socioeconomic and political change for the country, bringing both new opportunities and challenges for peace and security in Turkey and its role in such matters in regional and global contexts. Since the 2002 general elections, which erased a number of well-established political parties from the Turkish polity and brought the Adalet ve Kalkınma Partisi (AKP - Justice and Development Party) to power, Turkey has been going through a process of re-establishing its governance structures, revisiting political dynamics between civil and military actors and reforming internal power relations between the state, civil society and the market. The socioeconomic and political reform process that was primarily triggered by the country's official candidacy for membership to the EU at the Helsinki meeting in 1999 was extended further by the AKP with the implementation of six democratic harmonization packages by changing the constitution and various laws and regulations. However, the EU membership talks have come to an almost complete halt in recent years due to the Cyprus problem and resistance from some existing EU members towards Turkish membership. Nevertheless, the AKP government claims the negotiation process is still alive, implying that membership itself is not the main and only goal of the reform process.

On the other hand, it could be argued that, rather than reform, the main factor that has kept the AKP in power for over ten years is perhaps the government's handling of the Turkish economy. After a very long period of chronic economic instability with high inflation, foreign debt and unemployment challenges up to the early 2000 s, with many crises that several times collapsed the markets and crushed the banking system, the Turkish economy has been showing all signs of an enviable growth rate. Although Turkey's GDP per capita is still well below the EU average, the country's economic performance is often widely praised, especially considering that most EU countries have been experiencing serious economic problems over the last few years. With the winds of economic success behind them, Prime Minister Recep Tayyip Erdoğan and his party have so far won all national and local elections, including a couple of referendums, with big margins. In September 2012, the AKP voted for Erdoğan as its party leader for a third and final term. Such political and economic stability brought by a single-party government has been the main selling point for the AKP's popularity throughout the country. In fact, Turkey's strong stand against Israel on the Palestinian issue has made Prime Minister Erdoğan one of the most popular leaders in the Muslim world. On the other hand, during the AKP government's tenure, some serious fault lines also emerged in societal relationships in the country. 
The armed conflict between the security forces and the PKK has increasingly negated trust between the Turkish and Kurdish populations. Although the conflict between these communities has never become a fullblown civil war, the level of animosity, resentment and mistrust could be seen in different aspects of life. The provision of relief aid after the 2011 Van earthquake in Kurdish-dominated eastern Turkey, for example, clearly brought some of these societal problems to the surface. There were often such comments by Turks as 'Despite what the Kurds do against us and our country, we would still help them.' For a very long time throughout the armed conflict, the Turkish public generally perceived the insecurity issue to be a matter of PKK terrorism, but more and more the conflict now seems to be considered as one between Turks and Kurds. This is certainly a dangerous sign that might lead to a former-Yugoslaviastyle disintegration of the country.

The Kurdish-Turkish binary is in fact not the only fault line that seems to be appearing in the country's societal structures, as increasing divisions between Sunnis and Alevis, and secularists and Islamists have also been quite alarming. The so-called 'Ergenekon' trials for alleged crimes of aiming to overthrow the AKP government through organizing a military coup d'état, which have seen the arrest and imprisonment of a significant number of high-ranking army officers and generals, including some former chiefs of staff, have further inflamed such societal divisions. Secularists seem to be considering these trials as a deliberate attempt by the AKP government to minimize the military's role in the protection of the country's secular system of governance. The arrest of some journalists, authors and civil society representatives as part of these trials has also damaged the AKP's claims of ensuring freedom of thought in the country, though it is asserted that none of these journalists are imprisoned for their thoughts but for their actions in attempting to throw out a democratically elected government.

In the first part of this book, therefore, the main focus will be on democratization and social cohesion as the main umbrella theme of the country's human security challenge in the twenty-first century. Whether the specific challenges faced are environmental or economic, the key prerequisite for Turkey to respond to them effectively would still be its ability to reform its political structures, improve its democratic credentials and ensure the rule of law and the protection of human rights. The country is currently engaged in writing a new constitution. The present one was written by the 1980 military junta and since then amended many times to address its shortcomings in ensuring democratic, inclusive and just governance. The new constitution would certainly be a great opportunity for the country not only to address those governance-related challenges, but even to prepare the ground for a peaceful settlement of the Kurdish conflict. Therefore, the main objective of the book's 'Democratization and Social Cohesion' section is to investigate this critical challenge for the country. 
Thus to start the discussions in the first section, Özden Zeynep Oktav in Chapter 2, entitled 'Minority protection: a thorny issue in Turkish-EU relations', begins her investigation by questioning the meaning of 'minority' in the context of Turkey and how this differs from the international meaning of the concept. By using the EU-Turkey relationship as the main framework for its exploration, the chapter unpacks the issue of minority rights in relation to human security and presents the ways different 'minority' groups such as the Kurds, Alevis, Circassians, Syriacs and Romas in Turkey approach their group identity vis-à-vis the official minority groups of the country: the Jews, Armenians and Greeks. Further discussing minority rights in a specific case study, the third chapter, 'What went wrong with the "Romani Opening” in Turkey?', investigates the government's 'Romani Opening' as part of its recent democratization efforts. In her analyses of the major drawbacks of this process, Funda Gençoğlu Onbass discusses the notion of power using the speeches and press statements made by the AKP leadership and questions how this process was undertaken through different workshops and reported in the media. Finally, the chapter connects the Romani Opening to the discussion of human security in relation to the minority rights, discrimination and exclusion debates.

Bezen Balamir Cosskun and Halit Hakan Ediğ focus on a critical issue of the civil-military relationship in Chapter 4, 'Teaching national security or peace?: The case of the Turkish national curriculum'. The chapter reviews what the national security course was about and how it was taught. By undertaking such an analysis of a high-school course, the authors present a number of contemporary trends and recent changes in civil-military relations in Turkey and what impacts they will likely have on the democratization of the country in the near future. The chapter also discusses the need for peace-oriented education as an alternative to the redundant national security courses in Turkish high schools, in relation to peaceful coexistence within Turkish society as well as with neighbouring countries. Taking the theme of peace and coexistence further, Chapter 5 focuses on democratization, conflict transformation and the role of women's organizations in this process. Sanem Özer argues that increased participation of women in various levels and processes of decision-making and power through transnational advocacy networks would be a practical way of enhancing civil society's role in addressing human security and conflict transformation in Turkey. To unpack this relationship, she explores the way women's organizations could bridge different identities and build on commonalities through their local and transnational contacts.

The challenge of social cohesion is then explored through two quite different contexts and approaches. İhsan İkizer, in Chapter 6, 'Social exclusion and local authorities: a case study of İstanbul', focuses on the concepts of multidimensionality, partnership and participation in relation to local authorities and the potentially very significant role they could play 
in combating social exclusion. The roles of the sociocultural and political setting and factors that facilitate the implementation of the social inclusion principles by local authorities are also included. Moving from the western to the eastern border of Turkey, Giacomo Golinelli takes an anthropological approach to the social cohesion challenge in his chapter, 'Uncertain past, uncertain future, uncertain present: social cohesion and conflicts in Iğdır Province'. Chapter 7 argues that the usage of the notions of (mis) trust and social cohesion could help to tie, on the experiential and analytical levels, human security to the people of the province of Iğdır and their day-to-day lives. Based on Golinelli's extended stay in the field and involvement with events and people in Iğdır, this proves to be a particularly fruitful approach to understanding the role of trust and cohesion in human security in what seems to be an environment of customary mistrust and reciprocal suspicion.

Having looked at the challenge of democratization and social cohesion as an umbrella theme for human security at 'home', in the following section the book questions Turkey's claim to be an agent of peace and security 'abroad'. This is done through a selection of five chapters that investigate Turkey's regional and global roles through such issues as religion, migration, energy security and humanitarian assistance. These chapters sample some of the ways Turkey cooperates with its neighbours and the international community in general to assume an ambitious strategy in its contemporary foreign policy. To explain how an issue like religion could become a convergence point for Turkey's national and international human security perspectives, Chapter 8, 'Religion in Turkey's domestic and international agendas: human security perspectives' by Füsun Özerdem and Alan Hunter, focuses on how religion could contribute to social harmony and creativity and also engender violent conflict. Arguing that Turkey has the potential to play a constructive role in peace and security in relation to its neighbouring regions of the Middle East, Europe, the Balkans, the eastern Mediterranean, Central Asia and the Caucasus, the chapter focuses on the issues of secularism, religion and conflict in both domestic and international contexts. Finally, it presents a discussion of religion in the search for human security in the context of Turkey. To investigate the role of Turkey's religious heritage in addressing security challenges in the international context, Chapter 9, 'Turkey: bridging Europe and Islam' by Devrim Ümit, focuses on the trajectory of Turkey's potential EU membership and its possible impact on Muslim integration in the EU countries in the face of rising xenophobia, Muslim exclusion and political discrimination.

Chapter 10, on the other hand, presents a more conflictive relationship between Turkey and the EU. In her chapter entitled 'Securitization and externalization of the migration practices in the EU: readmission agreements and the Turkish case', Burcu Togral focuses on the issue of readmission agreements, one of the most significant ways the EU sends back 
irregular immigrants and asylum-seekers into countries of origin and transit. Taking Turkey as a case study, the chapter questions the implementation of such an agreement and its possible effects on the rights of migrants as a human security issue.

Chapter 11, 'Termination of the vendetta of the Black Sea? Stable peace, energy security and Russian-Turkish relations', by Reşat Bayer, investigates the way the Turkish-Russian relationship has improved substantially due to economic ties, particularly in reference to energy. Questioning whether such an improvement in bilateral relationships has had any implications for human security, the chapter uses the stable peace literature to connect macro- and micro-level security. Finally, the last chapter of this section focuses on Turkey's role in the provision of humanitarian aid to the Gaza Strip. In Chapter 12, 'Turkey's human security agenda in the Gaza Strip', Ibrahim Natil investigates the rhetoric and practice of Turkey's human security agenda in Palestine and the Gaza Strip in particular, as part of its foreign policy, following Hamas's victory in the Palestinian elections of 2006. Turkey's humanitarian aid response and efforts to resolve the intraPalestinian conflict between Hamas and Fatah from 2009 onwards provide the primary issues of focus in this chapter. Overall, in relation to Turkey's recent 'zero problems with neighbours' foreign policy doctrine, the chapter questions whether such an approach has increased Turkey's contribution to peace and security with its neighbours.

However, before those 11 chapters on human security challenges in relation to Turkey under the two main thematic areas as described above, the first chapter of this volume, by Oliver Richmond, presents the intellectual and policy evolution of human security since the 1994 UNDP report. The chapter, entitled 'Human(secur)ity and its subjects', argues that that evolution has echoed a tension between interests, pragmatism and a norm of humanity. The chapter also investigates how human security, as a policydriven or subject-driven concept and process, relies on both 'peace formation' capacity and international norms and capacity. On the other hand, as Richmond succinctly points out, despite human security's

externalized and policy-driven constraints, its connection with a grassroots and transnational will for humanity means its contestation is far from a simple matter of interests and capacity, and subject responses in everyday settings of peacemaking and peacebuilding mean it is difficult for internationals to do other than keep reinventing it.

\section{Note}

1 Turkey ranks one-hundred-and-forty-eighth out of 179 countries in Reporters Without Borders' 2011/2012 press freedom index (Reporters Without Borders 2012); it is labelled 'partly free' by Freedom House (2012); Transparency International's 2011 Corruption Perceptions Index ranks Turkey in sixty-first place, behind Oman, Jordan and Rwanda (Transparency International 2011). 


\section{Bibliography}

Annan, K. (2000) We the Peoples: The Role of the United Nations in the 21st Century, Report of the Secretary-General to the fifty-fourth session, New York: United Nations Department of Public Information.

Arat, Y. (2009) 'Religion, politics and gender equality in Turkey: implications of democratic paradox', UNRISD, September. Online. Available at: www.unrisd. org/80256B3C005BCCF9/ (httpPublications) /B49BF0AB76047D15C125765E00 47B1EB? OpenDocument (accessed 11 October 2011).

Axworthy, L. (2001) 'Human security and global governance: putting people first', Global Governance, 7(1): 19-23.

Bajpai, K. (2000) Human Security: Concept and Measurement, Kroc Institute Occasional Paper 19, Notre Dame: Kroc Institute.

Bekdil, B. (2012) 'Super turbo state Turkey', Hürriyet Daily News, 17 August. Online. Available at: www.hurriyetdailynews.com/super-turbo-state-turkey.aspx? PageID=238\&NID=27981\&NewsCatID=398 (accessed 19 August 2012).

Freedom House (2012) 'Freedom in the world 2012'. Online. Available at: www. freedomhouse.org/sites/default/files/FIW\%202012\%20Booklet_0.pdf (accessed 10 June 2012).

Glasius, M. (2008) 'Human security from paradigm shift to operationalization: job description for a human security worker', Security Dialogue, 39(1): 31-54.

Hampson, F.O. (2002) Madness in the Multitude: Human Security and World Disorder, Ontario: Oxford University Press.

International Crisis Group (2011) 'Turkey: ending the PKK insurgency', ICG Europe Report, no. 213. Online. Available at: www.crisisgroup.org/ /media/Files/ europe/turkey-cyprus / turkey/213\% 20Turkey\% 20-\% 20Ending\%20the\% 20 PKK\%20Insurgency.pdf (accessed 10 July 2012).

Karimova, N. and Deverell, E. (2001) Minorities in Turkey, Stockholm: Swedish Institute of International Affairs. Online. Available at: http://miris.eurac.edu/ mugs2/do/blob.pdf?type=pdf\&serial=1101210931437 (accessed 18 June 2012).

Kaya, N. (2009) 'Forgotten or assimilated? Minorities in the education system of Turkey', Minority Rights Group International Report. Online. Available at: www. minorityrights.org/download.php?id=632 (accessed 25 March 2012).

McClure, K.R. (2011) 'Turkey's eastern question: educational disparities and EU accession', Washington Review of Turkish E Eurasian Affairs, February. Online. Available at: www.thewashingtonreview.org/articles/turkeys-eastern-questioneducational-disparities-and-eu-accession.html (accessed 29 January 2012).

Müftüler-Baç, M. (2012) 'Gender equality in Turkey', European Parliament, January. Online. Available at: www.europarl.europa.eu/document/activities/cont/201202/ 20120207ATT37506/20120207ATT37506EN.pdf (accessed 5 April 2012).

Nef, J. (1999) Human Security and Mutual Vulnerability: The Global Political Economy of Development and Underdevelopment, Ottawa: IDRC.

Öztürk, İ. (2007) 'Economic and social issues of east and southeast Turkey: policy implications', MPRA Paper, no. 1582. Online. Available at: http://mpra.ub.unimuenchen.de/1582/1/MPRA_paper_1582.pdf (accessed 23 April 2011).

Pope, H. and Pope, N. (2011) Turkey Unveiled: A History of Modern Turkey, New York: The Overlook Press.

Rankin, B.H. and Aytaç, I.A. (2006) 'Gender inequality in schooling: the case of Turkey', Sociology of Education, 79(1): 25-43. 


\section{Introduction}

Reed, L. and Tehranian, M. (1999) 'Evolving security regimes', in M. Tehranian (ed.), Worlds Apart: Human Security and Global Governance, London: I.B. Tauris.

Reporters Without Borders (2012) 'Press Freedom Index 2011/2012', 25 January. Online. Available at: http://en.rsf.org/press-freedom-index-2011-2012,1043. html (accessed 10 June 2012).

Rugman, J. (2001) Atatürk's Children: Turkey and the Kurds, London: Continuum International Publishing Group.

Saatçi, E. and Akpinar, E. (2007) 'Assessing poverty and related factors in Turkey', Croatian Medical Journal, 48(5): 628-35.

Sevinç, K. (2011) 'Gender equality in Turkey: CHP's policy proposals', Social Europe Journal, 16 March. Online. Available at: www.social-europe.eu/2011/03/genderequality-in-turkey-chps-policy-proposals/ (accessed 11 November 2011).

Transparency International (2011) 'Corruption Perceptions Index 2011'. Online. Available at: www.transparency.org/content/download/64426/1030807 (accessed 10 June 2012).

UNDP (1994) Human Development Report 1994, New York: Oxford University Press.

UNDP (2011) Human Development Report 2011. Online. Available at: http://hdr. undp.org/en/media/HDR_2011_EN_Tables.pdf (accessed 10 June 2012).

USAK (2012) 'USAK report, no. 12-01: "Violence against women in Turkey", 8 March. Online. Available at: www.usak.org.tr/EN/haber.asp?id=1509 (accessed 9 April 2012).

Uvin, P. (2004) 'What is "human security"? Comments by 21 authors', Security Dialogue, 35(3): 347-87.

World Directory of Minorities and Indigenous Peoples (2011) 'Turkey overview', November. Online. Available at: www.minorityrights.org/?lid=4387 (accessed 2 July 2012).

World Economic Forum (2010) The Corporate Gender Gap Report 2010. Online. Available at: https://members.weforum.org/pdf/gendergap/corporate2010.pdf (accessed 10 July 2011). 


\section{References}

\section{Introduction}

Annan, K. (2000) We the Peoples: The Role of the United Nations in the 21st Century, Report of the SecretaryGeneral to the fifty-fourth session, New York: United Nations Department of Public Information.

Arat, $Y$. (2009) 'Religion, politics and gender equality in Turkey: implications of democratic paradox', UNRISD, September. Online. Available at: uudu. unrisd.

Axuorthy, L. (2001) 'Human security and global governance: putting people first', Global Governance, 7(1): 19-23.

Bajpai, K. (2000) Human Security: Concept and Measurement, Kroc Institute Dccasional Paper 19, Notre Dame: Kroc Institute.

Bekdil, B. (2012) 'Super turbo state Turkey', Hürriyet Daily Neus, 17 August. Online. Available at:

uulu. hurr iyetdailyneus. com/super- turbo-state- turkey. aspx? PageID=2388NID=279818NeusCat ID=398（accessed 19 August 2012).

Freedom House (2012) 'Freedom in the world 2012'. Online. Available at: แulu.

Glasius, M. (2008) 'Human security from paradigm shift to operationalization: job description for a human security worker', Security Dialogue, 39(1): 31-54.

Hampson, F.0. (2002) Madness in the Multitude: Human Security and World Disorder, ontario: oxford University Press.

International Crisis Group (2011) 'Turkey: ending the PKK insurgency', ICG Europe Report, no. 213. Online. Available at: uulu.crisisgroup.org/ $/ \%$ media/Files/ europe/turkeycyprus/turkey/213\%20Turkey\%20-820Ending $\% 20$ the $\% 20$ PKK820Insurgency.pdf (accessed 10 July 2012).

Karimova, N. and Deverell, E. (2001) Minorities in Turkey, Stockholm: Suedish Institute of International Affairs. Online. Available at: http://miris.eurac.edu/ mugs $/$ do/blob.pdf?type=pdf 8 serial=1101210931437 (accessed 18 June 2012).

Kaya, N. (2009) 'Forgotten or assimilated? Minorities in 
the education system of Turkey', Minority Rights Group International Report. Online. Available at: wulu. minorityrights.org/download.php?id=632 (accessed 25 March 2012).

McClure, K.R. (2011) 'Turkey's eastern question: educational disparities and EU accession', Washington Revieu of Turkish \& Eurasian Affairs, February. Online. Available at: wuw. thewashingtonreview.org/articles/turkeyseastern-question- educational-disparities- and-euaccession.html (accessed 29 January 2012).

Müftüler-Bac, M. (2012) 'Gender equality in Turkey', European Parliament, January. Online. Available at: uuw. europar l. europa. eu/document/act ivit ies/cont/201202/ 20120207ATT37506/20120207ATT37506EN.pdf (accessed 5 April 2012).

Nef, J. (1999) Human Security and Mutual Vulnerability: The Global Political Economy of Development and Underdevelopment, ottaua: IDRC.

Öztürk, I . . (2007) 'Economic and social issues of east and southeast Turkey: policy implications', MPRA Paper, no. 1582. Online. Available at: http://mpra.ub.unimuenchen.de/1582/1/MPRA_paper_1582.pdf (accessed 23 April 2011).

Pope, H. and Pope, N. (2011) Turkey Unveiled: A History of Modern Turkey, New York: The Overlook Press.

Rankin, B.H. and Aytaç, I.A. (2006) 'Gender inequality in schooling: the case of Turkey', Sociology of Education, 79(1): 25-43. Reed, L. and Tehranian, M. (1999) 'Evolving security regimes', in M. Tehranian (ed.), Worlds Apart: Human Security and Global Governance, London: I.B. Tauris. Reporters without Borders (2012) 'Press Freedom Index 2011/2012', 25 January. Online. Available at: http:/en.rsf.org/press- freedom-index- 2011-2012, 1043. html (accessed 10 June 2012). Rugman, J. (2001) Atatürk's Children: Turkey and the Kurds, London: Continuum International Publishing Group. Saatçi, E. and Akpınar, E. (2007) 'Assessing poverty and related factors in Turkey', Croatian Medical Journal, 48(5): 628-35. Sevinc, K. (2011) 'Gender equality in Turkey: CHP's policy proposals', Social Europe Journal, 16 March. Online. Available at: uulu.social - europe.eu/2011/03/gender- equality-inturkey-chps-policy-proposals/ (accessed 11 November 2011). Transparency International (2011) 'Corruption Perceptions Index 2011'. Online. Available at: 
uluw . transparency . org/content/down load/64426/1030807

(accessed 10 June 2012). UNDP (1994) Human Development

Report 1994, New York: 0xford University Press. UNDP (2011)

Human Development Report 2011. Online. Available at:

http:/hdr. undp.org/en/media/HDR_2011_EN_Tables.pdf

(accessed 10 June 2012). USAK (2012) 'USAK report, no.

12-01: "Violence against women in Turkey" ', 8 March.

Online. Available at: uwu.usak.org.tr/EN/haber.asp?id=1509

(accessed 9 April 2012). Uvin, P. (2004) "What is "human

security"? Comments by 21 authors', Security Dialogue,

35(3): 347-87. World Directory of Minorities and Indigenous Peoples (2011) 'Turkey overview', November. Online.

Available at: wum.minorityrights.org/?lid=4387 (accessed 2 July 2012). World Economic Forum (2010) The Corporate Gender Gap Report 2010. Online. Available at:

https://members. weforum. org/pdf/gendergap/corporate2010.pdf (accessed 10 July 2011). 


\section{Human(secur) ity and its subjects}

Bhabha, H.K. (1994) The Location of Culture, London, New York: Rout ledge.

Boege,. ., Broun, M.A., Clements, K.P. and Nolan, A. (2008) 'States emerging from hybrid political orders: Pacific experiences', Brisbane: Australian Centre for Peace and Conflict studies.

Canadian International Commission on Intervention and state Sovereignty (2003) The Responsibility to Protect, ottawa: IDRC.

Chandler, D. (2008) 'Human security: the dog that didn't bark', Security Dialogue, 39: 427-38. Claude, I. (1956) Suords into Ploughshares, New York: Random House. Davis, Jeff (2009) 'Liberal- era diplomatic language killed off', Embassy, 1 July. Online. Available at:

http://embassymag.ca/page/view/diplomatic_language 7-1-2009 (accessed 7 June 2012). Foucault, M. (1991)

'Governmentality', in G. Burchell, C. Gordon and P. Miller (eds), The Foucault Effect: Studies in Governmentality, Hemel Hempstead: Harvester wheatsheaf. Fourth High Level Forum on Aid Effectiveness (2011) 'Busan partnership for effective development co- operation', Busan, Republic of Korea, 29 November-1 December 2011. Hehir, A. (2011) 'The responsibility to protect and international law', in $P$. cunliffe (ed.), critical Perspectives on the Responsibility to Protect: Interrogating Theory and Practice, New York: Taylor \& Francis. Hoad, T.F. (1996) The oxford Concise Dictionary of Etymology, 0xford: 0xford University Press. Human Security Unit (2009) 'Human security unit: overvieu and objectives', New York: HSU. Independent Commission on International Development Issues (1980) North- South: A Programme for Survival, Cambridge, MA: MIT. International Labour Organization (1919/1934) Preamble to the Constitution, Geneva: ILo. Keohane, R.o. and Nye, J.S. (1987) 'Pouer and interdependence revisited', International Organization, 41(4): 725-53. Keohane, R.0. and Nye, J.S. (1998) 'Power and interdependence in the information age', Foreign Affairs, 77(5). Online. Available at:

uulu.foreignaffairs.com/ art ic les/54395/robert o -keohane andjoseph $s$-nye $\mathrm{j} r$ pouer andinterdependence- in-theinformation-age (accessed 8 September 2012). Locke, J. (1988 [1689]) 'Second treatise on government', in P. Laslett (ed.), Two Treatises on Government, Cambridge: Cambridge University Press. MacFarlane, S.N. and Khong, Y.F. (2006) Human Security and the INA: A Critical History, Bloomington: Indiana University Press. Mitrany, M. (1943) A 
Working Peace System, Oxford: Oxford University Press. Nandy, A. (1983) The Intimate Enemy: Loss and Recovery of Self under Colonialism, Oxford: Oxford University Press. Newnan, E. (2004) 'A normatively attractive but analytically weak concept', Security Dialogue, 35: 358-9. Neuman, E. (2010) 'Critical human security studies', Review of International Studies, 36: 77-94. Newman, E. and Richmond, 0.P. (eds) (2002) The United Nations and Human Security, London: Macmillan. OECD- DAC (2007) 'Principles for good international engagement in fragile states and situations', April, Paris: DECD. Paffenholz, T. (ed.) (2010) Civil Society and Peacebuilding, Boulder, Co: Lynne Rienner. Paris, R. (2001) 'Human security: paradigm shift or hot air?', International Security, 26(2): 87-102. Ponzio, R. (2005) 'Why human security is a new concept with global origins', St Antony's Review, 1(2): 66-71. Pugh, M. (2010) 'Towards life welfare', in E. Newman, R. Paris and 0 . Richmond (eds), New Perspectives on Liberal Peacebuilding, Basingstoke: Palgrave.

Pugh, M., Cooper, N. and Turner, M. (2008) The Political Economy of Peacebuilding, London: Palgrave.

Richmond, O.P. (2002) Maintaining Order, Making Peace, London: Palgrave.

Richmond, O.P. (2005) The Transformation of Peace, London: Palgrave.

Richmond, 0.P. (2008) Peace in International Relations, London: Rout ledge.

Richmond, O.P. (2009a) 'Eirenism and a post- liberal peace', Review of International Studies, 35(3): 557-80.

Richmond, 0.P. (2009b) 'The intellectual history of human security', in S. Peou (ed.), Human Security in East Asia, London: Rout ledge.

Richmond, 0.P. (2011a) 'Post-colonial hybridity and the return of human security', in D. Chandler (ed.), Critical Perspectives on Human Security, London: Routledge.

Richmond, O.P. (2011b) 'Critical agency, resistance, and a post-colonial civil society', Cooperation and conflict, $46(4): 419-40$.

Richmond, O.P. (2012) 'Dilemmas of a hybrid peace', unpublished. 
Richmond, 0.P. (2013) Failed Statebuilding versus Peace

Formation, New Haven: Yale University Press, forthcoming.

Roosevelt, F. (1941a) Annual Message to Congress, 6

January, The American Presidency Project. Online. Available at: uum.presidency.ucsb.edu/us/index. php?pid=16092 (accessed 23 June 2012).

Roosevelt, F. (1941b) The Public Papers and Addresses of Franklin D. Roosevelt, vol. 9, New York: Macmillan.

Sabaratnam, M. (2011) 'IR in dialogue. But can we change the subjects? A typology of decolonising strategies for the study of world politics', Millennium: Journal of International studies, 39(3): 781-803.

Schmeidl, S. (with Karokhail, M.) (2009) " "Prêt-a- porter states": How the McDonaldization of state- building misses the mark in Afghanistan', in M. Fischer and B. Schmelzle (eds), Peace in the Absence of States: Challenging the Discourse on State Failure, Building Peace Berghof Handbook for Conflict Transformation Dialogue Series 8.

Scholte, J.A. (2011) 'Reinventing global democracy', unpublished paper.

Tadjbakhsh, S. and Chenoy, A.M. (2006) Human Security: Concepts and Implications, London: Routledge.

Therien, J.-P. (2012) "Human security: the making of a UN ideology', Global society, 26(2): 191-213.

United Nations (UN) (2004) Report of the High- level Panel on Threats, challenges and Change, New York: United Nations.

UN (2007) 'Support by the United Nations system of the efforts of governments to promote and consolidate new or restored democracies', Preamble to United Nations General Assembly Resolution 7, session 62, New York: United Nations.

UN (2008) 'United Nations peacekeeping operations: principles and guidelines', New York: United Nations.

UN (2009a) 'Peacebuilding Commission Working Group on Lessons Learned: lessons learned from national dialogue in post- conflict situations', New York: United Nations.

UN (2009b) 'Guidance note of the Secretary- General on 
democracy', New York: United Nations.

UN Secretary-General (2009a) 'Implementing the responsibility to protect: report of the secretaryGeneral', A/63/677, 12 January. UN Secretary- General (2009b) 'Report of the Secretary- General on peacebuilding in the immediate aftermath of conflict', $A / 63 / 881,11$ June. UN Secretary- General (2010) 'Human security: report of the Secretary- General', A/64/701, 8 March. UNDP (1994) Human Development Report 1994, New York: 0xford University Press. UNDP (2012) Governance for Peace, New York: UNDP. van Tongeren, P. (1998) 'Exploring the local capacity for peace', in P. van Tongeren (ed.), Prevention and Management of Violent Conflicts, Utrecht: European Platform for Conflict Prevention and Transformation. Wolfers, $A$. (1952) "National security" as an ambiguous symbol', Political Science Quarterly, 67: 481-502. World Bank (2011) World Development Report 2011, Washington, DC: World Bank. World Commission on Environment and Development (1987) Dur Common Future, 0xford: Dxford University Press. Zanotti, L. (2010) 'UN integrated peacekeeping operations and NGOS', International Peacekeeping, 17(1): 17-31. 


\section{Minority protection: a thorny issue in Turkish-EU relations}

Aksoy, I . (2006) 'Birles, mis. Milletlerin azlnllk tarifi ve Kürt sorunu’, Navkurd. Online. Available at:

uluu.navkurd.net/nivisar/aksoy/kurt_sorunu.htm (accessed 10 December 2008).

Alçı, N. (2006) 'Bar 1 s, 1 h bas, kenti diken üstünde', Aks, am. 11 February.

Bianet (2004) "I . stanbul and "Avrupa Birlig" i ve Kürtler" ', Bag" 1 ms 12 I . letis, im Ag" 1 News Centre, 28 December.

Boyaci, s. . (n.d.) 'The EU harmonization process and the Syriacs'. Online. Available at: uubu.suryaniler.com/konukyazar lar.asp?id=319 (accessed 18 November 2008).

Çalis, lar, 0. (2008) 'Aleviler ne istiyor?', Radikal, 13 November.

Camurog' lu, R. (1998) 'Alevi revivalism in Turkey', in T. 0lsson, E. Özdalga and C. Raudvere (eds), Alevi Identity: Cultural, Religious and Social Perspectives, I . stanbul: Suedish Research Institute.

de Witte, B. (2004) 'The constitutional resources for an EU minority protection policy', in G. Toggenburg (ed.), Minority Protection and the Enlarged European Union: The Way Forward, Budapest: apen Society Institute.

Delanty, G. and Rumford, C. (2005) Rethinking Europe: Social Theory and the Implications of Europeanization, London: Rout ledge.

European Commission (2008) Enlargement Strategy and Main Challenges 2008-2009, Brussels: Commission of the European communities.

Gülalp, H. (2006) 'Citizenship vs. nationality?', in Gülalp (ed.), citizenship and Ethnic Conflict challenging the Nation State, London: Routledge.

Gunter, M.M. (2007) 'Turkey's floundering EU candidacy and its Kurdish problem', Middle East Policy, 14(1): 117-23.

Gurbetog' lu, c. (2008) 'Alevis want equal citizenship', Evrensel, 21 June. Online. Available at:

uum. alevihaberajansi. com/index. php?opt ion=com_content 8 task= 
Hughes, J. and Sasse, G. (2003) 'Monitoring the monitors: EU enlargement conditionality and minority protection in the CEECs', Journal on Ethnopolitics and Minority Issues in Europe, 1(8): 1-38.

I

- nanç, Bartın (2001) 'Süryani köylerine ilis, kin genelge', Milliyet, 15 June. Koçan, G. and öncü, A. (2004) 'Citizen Alevi in Turkey: beyond confirmation and denial', Journal of Historical Sociology, 17(4): 464-89. Käker, L. (2010) "A key to the "democratic opening": rethinking ethnicity, citizenship and Turkish nation state', Insight Turkey, 12(2): 49-69. Kymlicka, w. and 0palski, M. (2001) Can Liberal Pluralism Be Exported? Western Political Theory and Ethnic Relations in Eastern Europe, New York: 0xford University Press. Liotta, P.H. and Dwen, T. (2006) 'Why human security?', Whitehead Journal of Diplomacy and International Relations, 7(1): 37-54. Matbaacilik, G. (2008) Demokratik Toplum Partisinin Kürt Sorununa I . lis.kin Cözüm Projesi, Ankara: Demokratik Toplum Partisi. Milliget (2006) 'Alevilerin taleplerine Celik'ten ilımlı yanit', 7 September. Milliyet (2007) 'Three- stage reform package for the Alevis', 24 November. Minority Rights Group International (2007) 'A quest for equality: minorities in Turkey'. Online. Available at:

wuw. minor ityrights.org/dounload. php?id=432 (accessed 28 January 2009). Office of the High Commissioner for Human Rights (n.d.) 'Fact sheet no. 18 (rev.1), minority rights'. Online. Available at:

wulu . ohchr . org/Documents/Publ icat ions/FactSheet 18rev. 1en. pdf (accessed 28 January 2009). Öktem, K. (2008) 'Being Muslim at the margins and the AKP', Middle East Report, June. online. Available at: uudu.merip.org/mer/mer246/oktem.html (accessed 30 January 2009). Önderog' lu, E. (2009) 'The Pro- Kurdish party closed down by the constitutional Court', Bianet, 14 December. Online. Available at: http://bianet.org/english/minorities/118850-prokurdish-dtp-closed-doun- by-constitutional- court (accessed 15 December 2009). Oran, B. (2001) 'Süryani genelgesi ve paranoya', Agos, June. Online. Available at: uuu. ba.metu.edu.tr/ adil/baskin/index51-100.html (accessed 18 December 2009). Oran, B. (2003) 'Ulusal egemenlik kavraminın donüs, ümü, azınlıklar ve Türkiye'. Online. Available at:

uulu. anayasa.gov.tr/files/pdf/anayasa_yargisi/anyarg20/b_ oran.pdf (accessed 15 December 2009). Oran, B. (2006) 'Counter indictment', 15 February. Online. Available at: 
http:// baskinoran.com/makale/Minorityreportaffair-

Regent Journal.pdf (accessed 15 December 2009). Pospisil, I. (2006) 'The protection of national minorities, and the concept of minority in the EU law', Paper to be presented at ECPR 3rd Pan- European Conference Bilgi University, I . stanbul, 21-23 September 2006. Poyraz, B. (2006) 'EU minority perspective and the case of Alevilik in Turkey', European University Institute Robert Schuman Centre for Advanced Studies Mediterranean Programme Series, EU Working Paper RSCAS No. 2006/24. Radikal (2004) 'Zorunlu din dersi AI. HM'de', 6 June. Online. Available at: wum. radikal. com. tr/haber . php?haberno=1214248tar ih=06/07/2004 (accessed 18 December 2009). Radikal (2008) 'Alevilik düg' ümünün çözümü’, 11 January. Roma Foundation (2008) 'Urban renewal or ethnic relocation?', July. Online. Available at: uudu.rroma.org/reports/dounloads/sulukule.pdf (accessed 5 September 2009). Sabah (2008) 'Sünniler hem azınlıktır hem çog' unluk', 13 June.

Sabah (2011) 'Turkish election board blocked independent candidates', 19 April.

Sazak, D. (2004) 'Dindarleg' $1 \mathrm{~m} 1 \mathrm{z}$ deg' is, ime sorgulanmaya açiktir', Milliget, 2 February. Online. Available at: ulul. milliyet.com. tr/2004/02/02/siyaset/asiy. html (accessed 22 January 2009).

Thomsen, J. (2008) 'The Assyrians/Syriacs of Turkey: a forgotten people'. Online. Available at:

uulu.essays.se/essay/b92cce246e/ (accessed 20 December 2009).

Toksabay, B. (2005) 'Conflict over language rights: the case of Circassians and Kurds in Turkey', unpublished MA thesis.

Toktas., S. . (2006) 'EU enlargement conditions and minority protection: a reflection on Turkey's non- Muslim minorities', East European Duarterly, 40(4) : 489-518.

Turkish Daily Neus (2004) 25 February

Turkish Daily Neus (2008) 22 March.

Türmen, R. (2008) 'Zorunlu din dersi ve küçük Eylem' in açmazl', Milliget, 10 November.

Ulusoy, K. (2005) 'Turkey's reform effort reconsidered, 1987-2004', European University Institute Robert Schuman Centre for Advanced studies Mediterranean Programme Series, 
EUI Working Paper RSCAS No 2005/28. Online. Available at: wulu.eui.eu/RSCAS/WP- Texts/05_28.pdf (accessed 5 September 2009).

UNHCR (2008) 'Turkey: situation of Alevis (2005-May 2008)', Immigration and Refugee Board of Canada, 27 May. Online.

Available at: wutu.unhcr.org/refworld/docid/4885a91a2e.html (accessed 14 November 2008). 


\section{3 what went wrong with the 'Romani Dpening' in Turkey?}

Flyvbjerg', B. (2000) 'Ideal theory, real rationality: Habermas versus Foucault and Nietzsche', Paper for the Political Studies Association's 50th Annual Conference, The Challenges for Democracy in the 21st Century, London School of Economics and Political Science, 10-13 April 2000. Online. Available at: http://fyvajerg.plan. aau.dk/IdealTheory.pdf (accessed 21 December 2010).

Foucault, M. (1980) Power/Knowledge: Selected Interviews and 0ther writings 1972-1977, ed. C. Gordon, New York: Harvester wheatsheaf.

Foucault, M. (1988) The History of Sexuality vol. 1, New York: Vintage Books.

Fouinat, F. (2004) 'A comprehensive framework for human security', Conflict, Security and Development, 4(3): $289-97$.

Gooduin, M. (2004) 'The Romani claim to non- territorial nation status: recognition from an international legal perspective', European Roma Rights Centre. Online. Available at: wum.errc.org/cikk.php?cikk=1849 (accessed 7 January 2011).

Haylrlı, D. and Budak, Y. (2010) 'Açılımin Roman' l', Aksigon, 22 March.

Kende, $\dot{A}$. (2000) 'The Hungary of otherness: the Roma (Gypsies) of Hungary', Journal of European Area Studies, 8(2): $187-201$.

Kolukirık, S. (2007) 'The perception of Gypsies in Turkish society', Roma Rights Quarterly, 3: 31-6.

Kolukırık, S. and Toktas, S. . (2007) 'Turkey's Roma: political participation and organization', Middle Eastern Studies, 43(5): $761-77$.

Letsch, c. (2011) 'Turkish Roma make way for property developers in historic Istanbul district', Guardian, 9 November. Online. Available at: unulu.guardian.co.uk/ world/2011/nov/09/sulukule- roma-housingrou-istanbul? INTCHP=SRCH (accessed 30 0ctober 2012).

McCormack, T. (2008) 'Pouer and agency in the human security framework', Cambridge Review of International 
McDonald, M. (2002) 'Human security and the construction of security’, Global Society, 16(3): 277-95.

Marsh, A. and Karlldag', M. (2008) 'A study of research literature regarding Turkish Gypsies and the question of Gypsy identity', European Roma Rights Centre Country Reports Series, Issue 17. Online. Available at: uluu.ceeol.com (accessed 5 January 2011).

Milliget (2009) 'Roman açllıminda "Çingene" ayrllıg" l', 11 December.

Mouffe, c. (2000) The Democratic Paradox, London, New York: verso.

0lomoofe L. (2007) 'In the eye of the beholder: contemporary perceptions of Roma in Europe', European Roma Rights Centre. Online. Available at: umulu. errc.org/cikk.php?cikk=2881 (accessed 16 December 2010). Özden, S. (2009) 'Açllimda "Çingene" sitemi', Bugün, 11 December. Online. Available at: uulu.bugun.com. tr/haberdetay/86393-acilimda- cingene-sitemi- haberi. aspx (accessed 30 0ctober 2012). Özdil, Y. (2010) 'Roman'tizm', Hürriget, 17 March. Pouell, R. (2008) 'Understanding the stigmatization of Gypsies: pouer and the dialectics of (dis) identification', Housing, Theory and society, 25(2): 87-109. Sfeir- Younis, A. (2004) 'Violation of human rights is a threat to human security', Conflict, Security and Development, 4(3): 383-96. Thèrien, J.-P. (2012) 'Human security: the making of a UN ideology', Global society, 26(2): 191-213. Tzifakis, N. (2011) 'Problematizing human security: a general/contextual conceptual approach', Southeast European and Black Sea Studies, 11(4): 353-67. Wolin, S. (1996) 'Fugitive democracy', in S. Benhabib (ed.), Democracy and Difference: Contesting the Boundaries of the Political, Princeton: Princeton University Press. Yllmaz, M. and Köse, F. (2010) 'Açllımin içi doldurulsun', Cumhuriyet, 18 March. 


\section{Teaching national security or peace? The case of the Turkish national curriculum}

Altinay, A. (1999) 'Askerlik Vazifesinden Milli Guvenlik Bilgisi'ne: Askerlik ve Egitim', Birikim, 125-6: 200-28.

Altınay, A. (2000) 'Egitimin militarizasyonu: zorunlu milli guvenlik dersi', in A. Insel and A. Bayramoglu (eds), Bir Zumre, Bir Parti, Turkiye'de 0rdu, I . stanbul: Birikim vayinlari.

Altinay, A. (2003) 'Militarizm ve insan haklari ekseninde milli guvenlik dersi', in B. Cootuksöken, A. Erzan and 0. Silier (eds), Ders Kitaplarinda Insan Haklari: Tarama Sonuclari, I . stanbul: Türkiye Bilimler Akademisi ve Türkige Tarih Vakfi.

Apple, M.W. (1993) 'The politics of official knowledge: does a national curriculum make sense?', Teachers college Record, 95(2): 222-41.

Apple, M.W. and Christian- Smith, L.K. (1991) 'The politics of the textbook', in M.W. Apple and L.K. Christian- Smith (eds), The Politics of the Textbook, New York: Routledge.

Bartal, D. (2004) 'Nature, rationale, and effectiveness of education for coexistence', Journal of social Issues, $60(2): 253-71$.

Biesta, G. (2009) 'Good education in an age of measurement: on the need to reconnect with the question of purpose in education', Educational Assessment, Evaluation and Accountability, 21(33): 33-46.

Bilgin, P. (2007) " "Only strong states can survive in Turkey's geography": the uses of geopolitical truths in Turkey', Political Geography, 26: 740-56.

Cappelle, G., Crippin, G. and Lundgren, U. (2010) Emerging Global Dimensions in Education, London: CICE.

Cayir, K. (ed.) (2010) Egitim, Catisma ve Toplumsal Baris: Turkige'den ve Dunyadan Ornekler, I . stanbul: Tarih Vakfi Yayinlari.

Cotuksözen, B., Erzan, A. and Silier, 0. (eds) (2003) Ders Kitaplarinda Insan Haklari: Tarama Sonuclari, I . stanbul: Tarih Vakfi. 
Demirciog' lu, I.H. (2006) 'Comparison and evaluation of general aims of the teaching of history between Turkey and EU countries', Firat University Social Sciences Journal, $16(2)$ : $133-46$.

HaberTurk (2010) 'Milli guvenlik dersi kaldirilsin teklifi', 8 October. Online. Available at:

wuw. haberturk. com/gundem/haber/559478-milliguvenlik-dersi-kaldirilsinteklifi (accessed 16 July 2012).

Hahn, C.L. (1985) 'The status of nuclear education in social studies: report of a survey', Social Studies, 76 : 247-53. Hyman, H.H. and Wright, C.R. (1979) Education's Lasting Influence on values, Chicago: Chicago University Press. Inal, K. (2004) Egitim ve Iktidar: Turkiye'de Ders Kitaplarinda Demokratik ve Milliyetci Degerler, Ankara: Utopya Yayinevi. Langton, K.P. (1969) Political Socialization, Boston: Little, Brown. McClosky, H. and Brill, A. (1983) Dimensions of Tolerance: that Americans Believe about Civil Liberties, New York, Russell sage Foundation. Milli Eg itim Bakanllg 1 (2007) Milli Güvenlik Ders Kitabı [National Security Coursebook], Ankara: Devlet Kitapları Direktörlüg ü [State Books Directorate]. öztürk, I.H. (2011) 'Problem of anachronism in history teaching: an analysis of fictional texts in social studies and history textbooks', Journal of social Studies Education Research, 2(1): 37-58. Republic of Turkey Ministry of Education (1998) 'Milli guvenlik bilgisi ders programi - TC Milli Egitim Bakanligi Talim ve Terbiye Kurulu Baskanligi, karar sayisi 15' ['National security course syllabus as approved by Turkish Ministry of Education, decision no. 15'], Ankara: Ministry of Education. Sears, D.0. (1975) 'Political socialization', in F.I. Greenstein and N.W. Polsby (eds), Handbook of Political Science, Vol. 2, Reading, MA: Addison and Wesley. Today's Zaman (2010) 'National security courses: militarism in education', $25 \mathrm{April}$. Online. Available at:

wuw. todayszaman.com/newsDetail_getNewsById.action; jse ssionid=06A401A2E3BEE366706CD94EB8380251?news Id =208410 (accessed 16 July 2012). Turmuklu, A. and Sahin, I. (2006) 'Ilkogretim okullarinda catisma cozum strateilerinin karsilastirmali olarak incelenmesi', Cagdes Egitim Dergisi, 4: 11-21. United Nations (1999) 'Resolution on peace education', UN A/RES/53/2436. United Nations Educational, Scientific and Cultural organization (2005) Framework for Teachers, New Delhi: UNESCO. Yildirım, A. (1999) 'An assessment of high school history textbooks in Turkey: teachers' and students' perceptions', Paper presented at the annual meeting of the American Educational Research Association, Montreal, 19-23 April. Y1ld12, 0. (2003) 
'Turkiye'de tarih ogretiminin sorunlari ve cozumleri', Erciyes Universitesi Sosyal Bilimler Dergisi, 2: 181-90. 


\section{Democratization, conflict transformation and women's organizations}

Ahmadi, A. (2012) 'Turkey PM Erdog' an sparks row over abortion', BBC Neus, 1 June. Online. Available at: uwu.bbc.co.uk/neus/uorld- europe-18297760 (accessed 17 July 2012).

Arat, Y. (2008) 'Contestation and collaboration: women's struggles for empowerment in Turkey', in k. Fleet, $s$. Faroghi and R. Kosaba (eds), The Cambridge History of Turkey, vol. 4, New York: Cambridge University Press.

Association for the support of Women Candidates (2010). "We ask the Prime Minister: where is the justice in that?', 21 october. Online. Available at: wulu. ka-

der .org. tr/en/basin . php?act=sayfa\&ido0=1168ido1=978menu= (accessed 17 July 2012).

Binder, C. and Richman, N. (n.d.) 'Feminist movements in Turkey”, AMARGI Group I . stanbul. Online. Available at: http://amargigroupistanbul. uordpress.com/ feminismin-turkey/feminist- movements-in- turkey/ (accessed 17 July 2012).

Brauch, H.G. (2008) 'Güvenlig' in yeniden kavramsallas. tirılması: bar 1 , güvenlik, kalkınma ve çevre kavramsal dörtlüsü’, Uluslararası Iliskiler, 5(18): 1-47.

Center on Law and Globalization (n.d.) 'Transnational advocacy networks and international policy'. Online. Available at: http:/clg.portalxm.com/library/ keytext.cfm?keytext_id=113 (accessed 26 July 2012).

Coalition for Sexual and Bodily Rights in Muslim Societies (n.d.) 'What is CSBR?'. Online. Available at:

uum.csbronline.org/about-csbr/uhat- is-csbr-2/ (accessed 17 July 2012).

Esim, S. and Cindog'lu, D. (1999) 'Women's organisations in 1990 s Turkey: predicaments and prospects', Middle Eastern Studies, 35(1): 178-88.

European Women's Lobby (2012) 'Say No to abortion ban! Support women in Turkey!', 4 June. Online. Available at: uulu. uomen lobby.org/spip.php?article 36218lang=en (accessed 17 July 2012).

Flying Broom (2009) 'Directory of women's organizations in Turkey'. Online. Available at: 
uulu. ucansupurge org/ver itabani/ver itabanien. php (accessed 17 July 2012).

Galtung, J. (1990) 'Cultural violence', Journal of Peace Research, 27(3): 291-305.

Hampson, F.0. (2008) 'Human Security', in P.D. Williams (ed.), Security Studies: An Introduction, London and New York: Rout ledge.

Hürriget Daily News (2010) 'Women's rights marred by violence in the Southeast', 15 January. Online. Available at: wulu.hurriyetdailynews.com/default .aspx?pageid= 438\&n=uoman- fighting-marred- by-violence- in-thesoutheast-2010-01-15 (accessed 17 July 2012).

Ilkkaracan, P. (2008) Deconstructing Sexuality in the Middle East: Challenges and Discourses, Hampshire: Ashgate.

Ilkkaracan, P. (2012) 'The "Turkish model": for whom?'. online. Available at: uutu. opendemocracy. net/5050/Pinarilkkaracan/turkish- model-for- uhom (accessed 17 July 2012).

Kamer Vakf 1 (2007) 'KAMER' in Feminizmi', 5 February. online. Available at: unu. kamer.org.tr/1-3.php (accessed 17 July 2012).

Kamer Vakf 1 (n.d.) 'Nasil bas, ladik?'. Online. Available at: uuulu.kamer.org.tr/1.php (accessed 17 July 2012).

Kandioti, D. (1997) Cariyeler, Bacilar, Yurttas, lar, Kadin Aras, termalar 1 Dizisi, I . stanbul: Met is Yayınlar 1.

Kardam, N. (2003) Women's Human Rights Training Programme, 1995-2003 Evaluation Report, I . stanbul: WhHR- New Ways.

Keashly, L. (1991) 'The potential complementarity of mediation and consultation uithin a contingency model of third party intervention', Journal of Peace Research, 28(1): $29-42$.

Keck, M.E. and Sikkink, K. (1998) Activists beyond Borders: Advocacy Netuorks in International Politics, New York: Cornell University Press.

Keck, M.E. and Sikkink, K. (1999) 'Transnational advocacy networks in international and regional politics', UNESCO. online. Available at: http://isites. 
Kennedy-Pipe, C. (2007) 'Gender and security', in A. Collins (ed.), Contemporary Security Studies, New York: oxford University Press.

Kerr, P. (2007) 'Human security', in A. Collins (ed.), Contemporary Security Studies, New York: Oxford University Press.

Lederach, J.P. (1997) Building Peace: Sustainable Reconciliation in Divided Societies, washington, DC: United States Institute of Peace.

Lipschutz, R.D. (ed.) (1995) On Security, New York: Columbia University Press.

Marsh, P. (1995) 'Grassroots statecraft', in R.D. Lipshutz (ed.), On Security, New York: Columbia University Press.

Mor Cat 1 Women's Shelter Foundation (n.d.) 'Dur story'. Online. Available at: umu.morcati.org.tr/en/sayfa/11/0urstory.html (accessed 17 July 2012).

Networked Social Movements (2012) 'Keck \& Sikkink: Activists Beyond Borders: Advocacy Networks in International Politics', 30 April. Online. Available at: http://netuorkmovements. wordpress. com/2012/04/30/439/ (accessed 26 July 2012).

Pruitt, D.G. (2005) 'Escalation, readiness for negotiation, and third-party functions', in I.W. Zartman (ed.), Escalation and Negotiation in International conflicts, New York: Cambridge University Press.

Ramsbotham, 0., Woodhouse, T. and Miall, H. (2005) Contemporary Conflict Resolution: The Prevention, Management and Transformation of Deadly Conflicts, Cambridge: Polity Press.

Rehn, E. and Sirleaf, E.J. (2002) 'Women, war and peace: the independent experts' assessment on the impact of armed conflict on women and women's role in peace- building', New York: United Nations Development Fund for Women. Dnline. Available at: uum.ucm.es/cont/descargas/documento7201.pdf (accessed 9 July 2012).

Rightful Women Platform (2011) Online. Available at: uluw. haklikadinplatformu. org/icerik/46-rightfulwomen-platform (accessed 17 July 2012).

Rothschild, E. (1995) 'What is security?', Daedalus, 
$124(3): 53-98$.

Tekin Yılmaz, T. (2005) 'Gọ̈̆'ün kadın yas, amı üzerindeki etkileri', Yüksek Lisans Tezi, TC Yüzüncü Yil

Üniversitesi, Sosyal Bilimler Enstitüsü, Sosyoloji Anabilim Dall. Online. Available at:

http://mighealth. net/tr/images/o/0e/Gocun_kadin_ yasami_uzerine_etkileri.pdf (accessed 26 July 2012).

Ullman, R.H. (2007) 'Redefining security', in B. Buzan and L. Hansen (eds), International Security, Vol. IV, London: Sage Fublications.

United Nations Democracy Fund (UNDEF ) (2012) Empowerment of Women citizens in Turkey Evaluation Report. Online. Available at: uuw.un.org/democracyfund/ Docs/Post8zoproject820evaluat ions/LDF TUR-07-197820Empouerment 820 of 820 Womenz20Citizens.pdf (accessed 17 July 2012).

UNDP (2011) Human Development Report 2011. Online. Available at: http://hdr. undp.org/en/media/HDR_2011_EN_Complete.pdf (accessed 17 July 2012).

UNDP in Turkey (2009) 'Women's place in Turkey is alarming'. Online. Available at: uwu. undp.org.tr/Gozlem2. aspx? WebSayfaNo=2196 (accessed 17 July 2012) . 


\section{Social exclusion and local authorities: a case study of Istanbul}

Allen, J., Cars, G. and Madanipour, A. (2000) Social Exclusion in European Neighbourhoods: Processes, Experiences and Responses, Brussels: European Commission.

Arlkbog' a, E. (2004) 'The process of change in government and governance: example of I . stanbul city council', unpublished Ph.D. thesis.

Bayer, $Y$. (2008) "I . stanbul'da "Kent Konseyi" figaskosu’, Arkitera.com, 16 May. Online. Available at: uulu. arkitera.com.tr/h28916-I . stanbulda-kentkonseyifiyaskosu.html (accessed 18 July 2011).

Bell, D. (1987) 'The world and the United States in 2013', Daedalus: Journal of the American Academy of Arts \& Sciences, $16(3): 1-32$.

Benington, J. and Geddes, M. (2001) 'Introduction: social exclusion, partnership and local governance - new problems, new policy discourses in the European Union', in M. Geddes and J. Benington (eds), Local Partnerships and Social Exclusion in the European Union, New York: Rout ledge.

Berghman, J. (1995) 'Social exclusion in Europe: policy context and analytical framework', in G. Room (ed.), Beyond the Threshold, Bristol: The Policy Press.

Cars, G., Healey, P., Madanipour, A. and de Magalhaes, C. et al. (2002) 'Transforming governance, institutionalist analysis and institutional capacity', in G. Cars et al. (eds), Urban Governance, Institutional Capacity and Social Milieux, Hampshire: Ashgate.

de Haan, A. (2000) 'Social exclusion: enriching the understanding of deprivation'. Online. Available at: uulu. sussex.ac.uk/cspt/documents/issue2-2.pdf (accessed 17 June 2011).

Elander, I. and Blanc, M. (2000) 'Partnerships and democracy: a happy couple in urban governance?', in H.T. Andersen and $R$. van Kempen (eds), Governing European Cities, Aldershot: Ashgate.

Erder S. and I . nciog' lu N. (2008) Türkiye'de Yerel Politikanın Yükselis, i: I . stanbul Büyüks, ehir Belediyesi Örneg i, 1984-2004 [The Emergence of Local Politics in 
Turkey, the Example of I . stanbul Metropolitan Municipality], I . stanbul: I . stanbul Bilgi

Universitesi.

European Commission (2001) 'European governance'. Online. Available at: http://eur-

lex.europa.eu/LexUr iServ/site/en/com/2001/com2001_0428eno1. pdf (accessed 10 June 2011).

European Commission (2008) Turkey 2008 Progress Report. Online. Available at:

http://ec.europa.eu/enlargement/pdf/press_corner/key documents/reports_ nov_2008/turkey_progress_report_en.pdf (accessed 13 June 2011).

Eurostat (2008) Europe in Figures: Eurostat Yearbook 2008 [2005 statistics]. Online. Available at:

http:/epp.eurostat.ec.europa.eu/cache/ITY_OFFPUB/KS -

CD-07001/EN/KS- CD-07-001-EN.PDF (accessed 23 June 2011).

General Directorate of Social Assistance and Solidarity, Turkey (2011) 'Joint inclusion memorandum document'. online. Available at: wuw. sosyalyardimlar.gov.tr/ $\mathrm{tr} / \mathrm{html} / 11639 /$ GKID- Activities-for- EU-Accession-Period (accessed 23 June 2011).

Governorship of I . stanbul (2007) I . stanbul I . stihdam Raporu. Online. Available at: uuu.

istanbul.gov.tr/images/duyurular/2007ist ihdam.pdf (accessed 29 June 2011).

IMM Women's Coordination Centre (2011) Online. Available at: wuw. ibbkkm. org/?shw=0\&dil=tr (accessed 12 June 2011).

ISMEK (2011) 'Statistics on health center in I .

stanbul'. Online. Available at: wuw.

I . stanbul Metropolitan Municipality (2007) 2007-2011

Stratejik Planı. Online. Available at:

I . Stanbul Metropolitan Municipality (2009) 'Spor ve Eg' itim Hizmetleri 2004-2009'. Online. Available at:

wulu. ibb.gov.tr/tr- TR/Documents/yatirimlar/egitim_ibb. pdf (accessed 28 June 2011).

I . stanbul Metropolitan Municipality (2010a) 'History of local governance in I . stanbul'. Online. Available at: wulu. ibb.gov. tr/enUS/Organization/MunicipalHistory/Pages/AnaSayfa.aspx (accessed 14 June 2011). 
I . stanbul Metropolitan Municipality (2010b) 'I . stanbul Kent Konseyi sivil toplumu bekliyor . . .' . Online. Available at: wum.ibb.gov.tr/tr- TR/Pages/Haber. aspx?NewsID=15978 (accessed 17 June 2011).

I . Stanbul Metropolitan Municipality (2011a) Online. Available at: uluu.ibb.gov.tr (accessed 21 June 2011).

I . stanbul Metropolitan Municipality (2011b) 'Sag' lık ve sosyal hizmetler'. Online. Available at: wulu. ibb.gov.tr/tr- TR/Documents/yatirimlar/saglik_ibb.pdf (accessed 18 June 2011).

I . Stanbul Metropolitan Municipality (2011c) 'Population in Istanbul'. Online. Available at: uulu.tuik.gov.tr/PreTablo.do?tb_id=398ust_id=11 (accessed 12 June 2011).

I . Stanbul Metropolitan Municipality (2012) 'Population and demographic structure in Istanbul'. Online. Available at: ululu. ibb.gov.tr/sites/ks/en- us/o-exploring-

I . Stanbul Sag lik A.S. (2011) Online. Available at: ululu.saglikas.com.tr/ (accessed 21 June 2011).

OECD (March 2008) 'OECD territorial revieus: Istanbul, Turkey'. Online. Available at:

uulu. oecd.org/regional/reg ionaldeve lopment/40317916.pdf (accessed 18 June 2011).

Office for National Statistics, Turkey (2011) 'Statistics on population'. Online. Available at:

wul. tuik.gov.tr/PreTablo.do?tb_id=258ust_id=8 (accessed 29 June 2011).

Pamuk, S. (2008) 'Globalization, industrialization and changing politics in Turkey', New Perspectives on Turkey, 38: $267-73$

Pierre, J. and Peters, B.G. (2000) Governance, Politics and the State, Hong Kong: Macmillan.

Spor A.S. (2011) 'Statistics on sports centres'. Online. Available at: uuu.sporas. com.tr/ (accessed 22 June 2011).

Tounsend, P. (1979) Poverty in the United Kingdom, London: Penguin.

Tsakloglou, P. and Papadopoulos, F. (2002) 'Aggregate level 
and determining factors of social exclusion in twelve European countries', Journal of European Social Policy, $12(3): 211-25$.

Turkish Grand National Assembly (2004) 'Büyüks, ehir Belediyesi Kanunu', 10 July. Online. Available at: wulu. tbmm. gov. $t r /$ kanunlar $/ k 5216$.html (accessed 22 June 2011).

Turkish Statistical Institute (2011a) 'I . lkög' retim net okullas, ma oranı'. Online. Available at:

wulu. tuik.gov. tr/Gosterge. do? id=36428metod=IlgiliGosterge (accessed 10 June 2011).

Turkish Statistical Institute (2011b) 'Adrese dayalı nüfus kaylt sistemi (ADNKS) sonuçlar 1' [Population statistics of Turkey]. Online. Available at: http://tuikapp.

tuik.gov.tr/adnksdagitapp/adnks.zul (accessed 18 June 2011). 
7 Uncertain past, uncertain future, uncertain present: social cohesion and conflicts in Ig̈dir Province

Villari, L. (1906) Fire and Suord in the Caucasus, London: T.F. Unwin.

Weber, M. (1978) Economy and Society: An Dutline of Interpretive Sociology, Berkeley: University of California Press (orig. publ. 1925).

Winichakul, T. (1994) Siam Mapped: A History of the GeoBody of a Nation, cited in S.E. Cornell (2002) 'Autonomy as a source of conflict: Caucasian conflicts in theoretical perspective', World Politics, 54(2): 253.

Yllmaz, E. (2010) 'Ziya Gökalp's political sociology', International Journal of Sociology and Anthropology, 2(3): 29-33. This page intentionally left blank 


\section{Religion in Turkey's domestic and international agendas: human security perspectives}

anon. (n.d.) 'Islam and Africa'. Online. Available at: uluw. is lamandafrica.com/ (accessed 10 June 2011).

Aras, B. (2008) 'Turkish policy touard Central Asia', Policy Brief, 1 April. Online. Available at:

Balkanalysis.com (2011) 'Turkey's developing role in Africa: interview with Mehmet 0zkan and Birol Akgun', 1 January. online. Available at:

Barchard, D. (1998) Turkey and the European Union, London: Centre for European Reform.

$\mathrm{BBC}$ (n.d.) 'The story of Africa'. Online. Available at: unulu. bbc . co. uk/uor ldservice/ africa/features/storyofafrica/index_section7.shtml (accessed 10 June 2011).

Cain, P. (2010) 'The limits of Turkey's Balkans diplomacy', World Politics Review, 10 November.

CNN Türk (2011) 'Dünyanın Müslüman nüfusu artıyor!', 27 January. Online. Available at: uluu. cnnturk. com/2011/dunya/01/27/dunyan in . mus luman . nuf usu. artiyor/604758.0/ (accessed 19 June 2011).

Davutog' lu, A. (2008) 'Turkey's foreign policy vision: an assessment of 2007', Insight Turkey, 10(1): 77-96.

Diganet (n.d.) Online. Available at:

wulu. diganet.gov. tr/turkish/dy/Diganet - Is leriBaskanligiAnakenu-istatistikler-561.aspx (accessed 20 June 2011).

Efegil, E. (2008) 'Turkish AK Party's Central Asia and Caucasus policies: critiques and suggestions', Caucasian Review of International Affairs, 2(3): 166-72.

Escobar, P. (2011) 'Turkey: the sultans of suing'. Asia Times, 7 April. Online. Available at: http://atimes.com/atimes/Middle_East/M007Ak02.html (accessed 17 July 2011).

Handrahan, L. (2002) Gendering Ethnicity: Implications for Democracy Assistance, New York: Routledge.

Jackay Kaba, A. (2005) 'Spread of Christianity and Islam in 
Africa: a survey and analysis of the numbers and percentages of Christians, Muslims, and those who practice indigenous religions', Western Journal of Black Studies, 29(2): 553-70.

Khalid, A. (2007) Islam After Communism: Religion and Politics in Central Asia, Berkeley, CA: University of California Press.

Knudsen, A. (2003) Political Islam in the Middle East, Bergen: Chr. Michelsen Institute.

Magister, S. (2004) 'Mission impossible: building a church in Turkey', 28 December. Online. Available at:

http://chiesa. espresso. repubblica. it/articolo/213937eng=y (accessed 23 June 2011).

Milton- Eduards, B. (2000) Contemporary Politics in the Middle East, Cambridge: Polity Press. Özerdem, F. (2011) 'Turkey as a bridge betueen Europe and Middle East: new goals, restricting facts', Management and Education, 7(2): 103-11. Özkan, M. (2008) 'Turkey discovers Africa: implications and prospects', SETA Policy Brief, September, No. 22. Özkan, M. (2010-11) 'Turkey's rising role in Africa', Turkish Policy Duarterly, 9(4): 93-105. Pew Research Center (2009) 'Mapping the global Muslim population', Pew Research Center, October. Online. Available at: 


\section{Turkey: bridging Europe and Is lam}

Allen, P. (2009) "Nicolas Sarkozy says the burqa is "not welcome" in France', Telegraph, 22 June. Online. Available at: uwu.telegraph.co.uk/news/uor ldnews/ europe/france/5603859/Nicolas- Sarkozy-says- the-burqais-not- welcome-in- France.html (accessed 29 July 2011).

Arslan, M. (2012) 'Bas, bakan'dan Periler'e soyunma odasında tebrik', Hürriget, 29 July. Online. Available at: umu. hurr iyet .com. tr/spor/basketbol/21091127.asp (accessed 29 July 2012).

Bulliet, R. (2004) The Case for Islamo- Christian Civilization, New York: Columbia University Press.

Bush, George H.W. (1990) 'Address before a joint session of the Congress on the Persian Gulf crisis and the Federal budget deficit', 11 September. Online. Available at:

Bush, George H.W. (1991) 'Address before a joint session of the Congress on the cessation of the Persian Gulf conflict', 6 March. Online. Available at: http://

Bush, George w. (2001) 'Presidential address to the nation', 7 october. Online. Available at:

http://georgeubushwhitehouse archives.gov/news/releases/2001/ 10/print/20011007-8.html (accessed 3 July 2012).

Chomsky, N. (2001) September 11, USA/Australia: Allen \& Unwin.

Chomsky, N. (2003) Power and Terror: Post- 9/11 Talks and Intervieus, New York: Seven Stories Press.

Cizre, U. (2003) 'Demythologizing the national security concept: the case of Turkey', Middle East Journal, 57(2): 213-29. Cizre, U. (2008) 'Introduction', in U. Cizre (ed.), Secular and Islamic Politics in Turkey: The Making of the Justice and Development Party, New York: Routledge. Council of Europe (2005) 'Annual report on ECRI's activities covering the period from 1 January to 31 December 2004'. online. Available at: uulu.coe.int/t/

Tadjbakhsh, S. and Chenoy, A.M. (2006) Human Security: Concepts and Implications, London: Routledge.

Telegraph (2006) 'Factbox: British National Party', 10 January. Online. Available at: 
uulu. te legraph. co. uk/neus/uknews/1399666/Factbox-

British-National- Party. html (accessed 29 July 2011).

Underhill, $\omega$. (2009) "Why fears of a Muslim takeover are all urong', Newsweek, 11 July.

UNDP (1994) Human Development Report 1994. Online.

Available at: http://hdr.

undp.org/en/reports/global/hdr1994/ (accessed 3 July 2012) . 


\section{Securitization and externalization of the migration practices in the EU: readmission agreements and the Turkish case}

European Commission (2004) Communication from the Commission to the Council and the European Parliament Recommendation of the European Commission on Turkey's Progress Towards Accession, 656 final, Brussels: European Commission.

European Commission (2012) Proposal for a Council Decision of [. . .] Concerning the Conclusion of the Agreement between the European Union and the Republic of Turkey on the Readmission of Persons Residing without Authorization, 239 final, Brussels: European Commission.

European Council on Refugees and Exiles (ECRE) (2012)

'Readmission Agreement between the EU and Turkey initialled', ECRE Weekly Bulletin, Brussels: ECRE.

European Union Agency for Fundamental Rights (FRA) (2011) Coping with a Fundamental Rights Emergency: The Situation of Persons Crossing the Greek Land Border in an Irregular Manner, Vienna: FRA.

Hebenton, B. and Thomas, T. (1995) Policing Europe, London: Macmillan.

House of Commons (2011) Implications for the Justice and Home Affairs area of the accession of Turkey to the EU: Tenth Report of Session 2010-12, London: The Stationery office.

Human Rights watch (2008) 'Stuck in a revolving' door: Iraqis and other asylum seekers and migrants at the Greece/Turkey entrance to the European Union'. Online. Available at:

Huysmans, J. (2006) The Politics of Insecurity: Fear, Migration and Asylum in the EU, London and New York: Rout ledge.

I

- çduggu, A. and Yükseker, D. (2010) 'Rethinking transit migration in Turkey: reality and re-presentation in the creation of a migratory phenomenon', Population, Space and Place, 18(4): 441-56. 
Karanja, S.K. (2000) 'The Schengen cooperation:

consequences for the rights of EU citizens', Mennesker og rettigheter, 18: 215-22.

Kaya, C. (2009) 'Procedural rights under Turkish law in the light of the EU asylum law', E- Journal of Ministry of Justice. Online. Available at: uulu. justice.gov.tr/ejournal/pdf/PROCEDURAL_\&20RIGHTS\&20.pdf (accessed 5 January 2012).

Kiris, ci, K. (2009) 'Harmonisation of migration policy and Turkey's security challenges', EDAM Discussion Paper Series, I . stanbul: Centre for Economics and Foreign Policy Studies.

Legomsky, H.S. (1993) 'Immigration, equality, and diversity', Columbia Journal of Transnational Law, 31: 319-35.

Migreurop (2009) 'Europe's murderous borders'. Dnline. Available at: wulu. migreurop.org/IMG/pdf/RapportMigreurop-nov2009-en- final.pdf (accessed 5 september 2011).

Migreurop (2009/10) 'European borders: controls, detention and deportation'. Online. Available at: wulu. migreurop.org/IMG/pdf/rapport - migreurop-2010-en__2-121110.pdf (accessed 5 September 2011).

Dsouska, D. (2010) 'Readmission agreements beyond legislation', Paper presented at European Consortium for Political Research, Dublin, August.

Peers, 5. (2003) 'Readmission agreements and EC external migration law', Statewatch Analysis no 17. Online. Available at: wulu.statewatch.org/news/2003/ may/12readmission.htm (accessed 5 June 2012). Republic of Turkey Ministry for EU Affairs (2008) 'National programme of Turkey for the adoption of the EU acquis'. Online. Available at: wulu.abgs.gov.tr/index. php?p=422608l=2 (accessed 5 September 2011). Schuster, L. (2011) 'Engendering insecurity: the EU asylum regime', in G. Lazaridis (ed.), Security, Insecurity and Migration in Europe, Surrey: Ashgate. Today's Zaman (2010) 'Hurdles remain on readmission agreement betueen Turkey and EU', 31 May. van Munster, R. (2009) Securitizing Immigration: The Politics of Risk in the EU, New York: Palgrave. Zapata- 
Barrero, R., Aubarell, G. and Aragall, X. (2009) 'New directions of national immigration policies: the development of the external dimension and its relationship with the Euro-Mediterranean process', EuroMesco Paper 79, February. 


\section{Termination of the vendetta of the Black Sea? stable peace, energy security and Russian-Turkish relations}

Akgün, M. (1994) 'Great Pouers and the Straits: from Lausanne to Montreux', Turkish Yearbook, 24: 57-86.

Aks, in, S. (2010) I . c Savas, ve Sevr'de ölüm, I . stanbul: I . S. Bankası kültür Yayınları.

Aktürk, S. . (2006) 'Turkish-Russian relations after the Cold War (1992-2002)', Turkish Studies, 7: 337-64.

Anderson, M. (1966) The Eastern Question, 1774-1923: A Study in International Relations, New York: St. Martin's Press.

Aykan, M.B. (1993) 'The Palestinian question in Turkish foreign policy from the 1950 s to the 1990s', International Journal of Middle East Studies, 25: 91-110.

Bach, Q. (1987) Soviet Economic Assistance to the Less Developed Countries: A Statistical Analysis, oxford: Clarendon Press.

Bahgat, G. (2011) Energy Security: An Interdisciplinary Approach, Hoboken, N.T: Wiley.

Batu, H. (1965) 'Türkige'nin d1s, sigaseti', D1s, is, leri Belleteni, 6 (March): 21-6.

Bayer, R. (2009) 'Barıs, ve ihtilaf çözümü', in N. Beriker (ed.), Cat is, madan Uzlas, maya: Süreçler ve vöntemler, I . stanbul: Bilgi University Press.

Bayer, R. (2010) 'Peaceful transitions and democracy', Journal of Peace Research, 47: 535-46.

Bayer, R. and Keyman, E.F. (2012) 'Turkey: an emerging hub of globalization and internationalist humanitarian actor?', Globalizations, 9: 73-90.

Bilgin, M. (2011) 'Energy policy in Turkey: security, markets, supplies and pipelines', Turkish Studies, 12: 399-417.

Bilgin, P. (2003) 'Individual and societal dimensions of security', International studies Review, 5: 203-22.

Blainey, G. (1988) The Causes of War, New York: Free Press. 
Boulding, K. (1978) Stable Peace, Austin: University of Texas Press.

Davutog' lu, A. (2001) Stratejik Derinlik, I . stanbul: Küre.

Deringil, S. (1989) Turkish Foreign Policy during the Second World War: An 'Active' Neutrality, Cambridge: Cambridge University Press.

Deutsch, K., Burrell, S.A. and Kann, R.A. (1957) Political Community and the North At lantic Area: International organization in the Light of Historical Experience, Princeton: Princeton University Press.

Ebel, R. (1994) Energy Choices in Russia, Washington, DC: Center for Strategic and International Studies.

Ecevit, B. (1978) 'Turkey's security policies', Survival, 20: 203-8.

Ediger, $V$. and Bag' dadi, I. (2010) 'Turkey-Russia energy relations: same old story, new actors', Insight Turkey, 12(3): 221-36.

EUActiv (2009) 'Ankara courts the EU over Nabucco gas supplies', 6 Dctober. Online. Available at:

undu. euractiv.com/europes- east/ankara- courts-eu-

nabuccogas- sup-neus- 222663 (accessed 29 July 2012).

Gül, A. (2007) 'Why is a non-permanent seat for Turkey at the United Nations Security Council important for herself, her region and the world?', Turkish Policy Quarterly, 6: $13-16$.

Hale, w. (2000) Turkish Foreign Policy, 1774-2000, Fortland, oR: Frank Cass.

Hürriget Daily News (2012) "Gazprom "warns" Turkey on gas deal', 30 June. Online. Available at:

uuw. hurr iyetdai lyneus.com/gazprom- warns-turkey- on-gasdeal. aspx ?page ID=2388nID=244228NeusCat ID=348 (accessed 29 July 2012).

I

manov, $v$. (2010) 'Türk-Rus ilis, kilerinde yakınlas, ma 
dönemleri', in Ç. Yenigün and E. Efegil (eds), Türkiye'nin Deg is, en D1s, Politikas1, Ankara: Nobel.

S. eri, E., özdemir, $V$. and Dilek, A.O. (2010) 'Jeopolitik rekabetten enerji is,birlig ine: Türkige-Rusya

ilis,kileri', in C. Yenigün and E. Efegil (eds), Türk D1s. Politikası Güncel Sorunlar, Ankara: Nobel.

Jelavich, B. (1964) A Century of Russian Foreign Policy, 1814-1914, Philadelphia: Lippincott.

Kacowicz, A. and Bar-Siman-Tov, Y. (2000) 'Stable peace: a conceptual framework', in A. Kacowicz, Y. Bar-Siman-Tov, 0 . Elgstrom and M. Jerneck (eds), Stable Peace among Nations, Lanham, MD: Rowman and Littlefield.

Kardas., S. . (2011) 'Geo- strategic position as leverage in EU accession: the case of Turkish-EU negotiations on the Nabucco pipeline', Southeast European and Black Sea Studies, 11: 35-52.

Karpat, K. (1975) 'Turkish Soviet relations', in K. Karpat (ed.), Turkey's Foreign Policy in Transition 1950-1974, Leiden, Nether lands: Brill.

Kelman, H. (1999) 'Transforming the relationship between former enemies: a social-psychological analysis', in $R$. Rothstein (ed.), After the Peace: Resistance and Reconciliation, Boulder, co: Lynne Rienner.

Kupchan, C. (2010) How Enemies Become Friends, Princeton: Princeton University Press.

Laçiner, s. (2010) 'Turkey's energy pipelines', Review of International Law and Politics, 5: 149-52.

Lenczouski, G. (1972) Soviet Advances in the Middle East, Washington, DC: American Enterprise Institute for Public Policy Research.

Macfie, A. (1989) 'The Turkish Straits in the Second World War, 1939-45', Middle Eastern Studies, 25(2): 238-48.

Mackenzie, D. (1967) The Serbs and Russian Pan- Slavism, 1875-1878, Ithaca, NY: Cornell University Press. 
Müftüler-Baç, M. and Bas, kan, D. (2011) 'The future of energy security for Europe: Turkey's role as an energy corridor', Middle Eastern Studies, 47: 361-78.

Özbay, F. (2011) 'The relations between Turkey and Russia in the 2000s', Perceptions, 16: 69-92.

Pamuk, S. . (1987) The 0ttoman Empire and European Capitalism, 1820-1913, Cambridge: Cambridge University Press.

Republic of Turkey Ministry of Foreign Affairs (2011) 'Turkey's energy strategy'. Online. Available at: uulu.mfa.gov.tr/turkeys- energy-strategy.en.mfa (accessed 29 August 2012).

Rich, N. (1992) Great Pouer Diplomacy, 1814-1914, New York: McGrau- Hill.

Rubinstein, A. (1982) Soviet Policy touard Turkey, Iran, and Afghanistan: The Dynamics of Influence, New York:

Praeger.

Sabah (2012) 'Türkige için en önemli ülke Irak', 27 April. online. Available at:

uluw. Sabah. com.tr/Ekonomi/2012/04/27/turkiye - icin-enonemli-ulke- irak (accessed 29 July 2012).

Sander, 0. (1986) 'Türk dis, Politikasında barıs, unsuru', in 2. Milli Egemenlik Sempozyumu, Ankara: Türkiye Büyük Millet Meclisi.

Sander, 0. (2006a) Anka'nın Yükselis, i ve Düs,üs,ü: 0smanlı diplomasi tarihi üzerine bir deneme, Ankara: I . mge.

Sander, 0. (2006b) Türkiye'nin D1s. Politikası, Ankara: I . mge.

Sasley, B. (2001) 'Turkey's energy politics', in B. Rubin and $K$. Kirisci (eds), Turkey in horld Politics: An Emerging Multiregional Pouer, Boulder, co: Lynne Reinner Publishers.

Selçuk, H. (2005) Türkige-Rusya Ekonomik I . lis,kileri, I - stanbul: Tasam.

Sezer, D. (1985) 'Peaceful coexistence: Turkey and the Near' East in Soviet foreign policy', Annals of the American Academy of Political and Social Science, 481: 117-26. 
Sezer, D. (2002) 'Türk-Rus ilis,kileri: düs, manlıktan 'fiili yakinlas, ma'ya', in A. Makovsky and S. Sayar 1 (eds), Türkige'nin Yeni Dünyası: Türk D1s. Politikasının Deg is, en Dinamikleri, I . stanbul: Alfa.

Sonyel, S. (1975) Turkish Diplomacy 1918-1923: Mustafa Kemal and the Turkish National Movement, Beverly Hills, CA: Sage Publications.

Sovacool, B.K. and Broun, M.A. (2010) 'Competing' dimensions of energy security: an international perspective', Annual Review of Environment and Resources, 35: 77-108.

Tanrisever, 0. (2003) 'Turkey and the Russian Federation: touards a mutual understanding?', in T. Ismael and $M$. Aydn (eds), Turkey's Foreign Policy in the Tuenty- First Century: A Changing Role in world Politics, Burlington, VT: Ashgate.

T.C. Moskova Büyükelçilig’ i Ticaret Müs, avirlig’ i (2012) '2011 Ylllik: Rusya D1s. Ticaretine ve Türkiye-Rusya I . kili I . lis,kilerine Yönelik Güncel I . statistikler'. Online. Available at: uulu . musavirlikler .gov. tr/upload/RF/2011820yillik.xls (accessed 29 July 2012).

Tekin, A. and Williams, P. (2011) Geo- Politics of the Euro- Asia Energy Nexus, New York: Palgrave.

Tellal, E. (2001) 'Ssc日'yle ilis,kiler', in B. Oran (ed.), Türk D1s. Politikası, I . stanbul: I . letis,im.

TüI . K (2011) Türkige I . statistik Ylll1g 1 , Ankara: Türkige I . statistik Kurumu.

Türkay, M., Yılmaz, S. . and San Akça, B. (2012)

Türkiye'nin Enerji verimlilig' i Haritası ve Hedefler, KüTEM Report, May.

Türkiye, Ekonomi Bakanlıg' 1 (n.d.) 'ülkelere göre dı. ticaret'. Online. Available at:

UNDP (1994) Human Development Report 1994, New York: 0xford University Press.

Yergin, D. (2006) 'Ensuring energy security', Foreign Affairs, 85: 69-82. 


\section{Turkey's human security agenda in the Gaza Strip}

Alresalah (2012) 'Turkish medical humanitarian aid arrives Gaza', 4 February. Online. Available at: uum.alresalah.ps/en/index.php?act=post\&id=124 (accessed 22 July 2012).

Aras, B. (2002) 'Turkey and the Palestinian question since al- Aqsa intifada', Alternatives: Turkish Journal of International Relations, 1(3): 49-63. Bennhold, K. (2009) 'Leaders of Turkey and Israel clash at Davos panel', New York Times, 29 January. Online. Available at: wuw. nyt imes. com/2009/01/30/world/ europe/30clash.html?_r=1 (accessed 22 July 2012). Cag'aptay, S. (2010) 'The AKP's Hamas policy I: how Turkey turned', Hürriyet Daily Neus, 29 June. Online. Available at: undu.cagaptay.com/7659/theakps-hamas-policy-i- hou-turkey- turned (accessed 22 July 2012). Davutog lu, A. (2010) Strategic Depth: Turkey's Role in the International Arena, Doha: Al Jazeera Centre for Studies. Eduards, B. and Farrel, S. (2010) Hamas, Cambridge: Polity Press. Hassan, Y.H. (2006) Turkey: A Search for the Future, Cairo: Egyptian Lebanese Al Dar. Hürriget Daily News (2012) 'Turkey aids Palestine by giving $\$ 118$ million', 21 May. Online. Available at: undu. hurr igetdai lyneus . com/turkey- aids-palestineby-giving- 118 million. aspx?page ID $=2388 n I D=21205$ \& NewsCat ID=344 (accessed 22 July 2012). Levy, G. (2010) The Punishment of Gaza, London: Verso. Maa'n Neus Agency (2011) 'Turkish PM reiterates support for Palestinian uN bid', 23 July. online. Available at: uum. maanneus. net/eng/viewDetails. aspx?ID=407691 (accessed 22 July 2012). Önal, c. (2011) 'Turkey could host mediation talks between Fatah and Hamas', Today's Zaman, 22 May. Online. Available at: undu.todayszaman.com/neus- 244745-turkey- could-hostmediation-talks-between-fatah- and-hamas.html (accessed 22 July 2012). Önis,, Z. (2011) 'Multiple faces of the new Turkish foreign policy: underlying dynamics and a critique', Insight Turkey, 13(1): 47-65. Rigby, A. (2010) Palestinian Resistance and Nonviolence, Jerusalem: PASSIA Publications. Roy, S. (2011) Hamas and civil Society in Gaza: Engaging the Islamist Social Sector. Princeton: Princeton University Press. Rubin, M. (2010) 'Erdog' an's Turkey is not a friend', Foruard, 11 June. Online. Available at: uum.michaelrubin.org/7556/erdoganturkey-not-friend (accessed 22 July 2012). Schanzer, J. (2008) Hamas vs. Fatah: The Struggle for Palestine, New York: Palgrave Macmillan. Shinoda, H. (2004) Conflict and Human Security: A Search for New Approaches of Peace- 
building, IPSHU English Research Report Series No. 19. Tamimi, A. (2007) Hamas: Unuritten Chapters, London: C. Hurst and Co. Publishers Ltd. Today's Zaman (2012) 'Hamas leader meets with Erdog' an in surprise visit', 16 March. online. Available at: uluu.todayszaman.com/neus274468-hamas- leadermeets- with-erdogan- in-surprisevisit.html (accessed $22 \mathrm{July} 2012$ ). Turkish International Cooperation and Development Agency (TI . KA) (n.d.). online. Available at: uuu.tika.gov.tr (accessed 22 July 2012). LNDP (1994) Human Development Report 1994, New York: 0xford University Press. Yinanc, B. (2009) 'Turkey and Israel: an alliance in trouble', Hürriyet Daily Neus, 31 December. Yinanc, B. (2010) 'Secret Turkish-Israeli military alliance launches relations', Hürriyet Daily Neus, 4 January. 


\section{Conclusion}

UNDP (1994) Human Development Report 1994, New York: 0xford University Press. 